\title{
Bovine Leukaemia Virus: Current Epidemiological Circumstance and Future Prospective
}

\author{
Marawan A. Marawan 1,2,3,*(D), Abdulaziz Alouffi ${ }^{4,5}$, Suleiman El Tokhy ${ }^{6}$, Sara Badawy ${ }^{7,8}$, \\ Ihsanullah Shirani 1,2,9 ${ }^{1}$, Ali Dawood 1,2,10, Aizhen Guo 1,2,11,*, Mashal M. Almutairi 5,12, \\ Fahdah Ayed Alshammari ${ }^{13}$ and Abdelfattah Selim ${ }^{3, *(D)}$
}

\section{check for} updates

Citation: Marawan, M.A.; Alouffi, A.; El Tokhy, S.; Badawy, S.; Shirani, I.; Dawood, A.; Guo, A.; Almutairi, M.M.; Alshammari, F.A.; Selim, A. Bovine Leukaemia Virus: Current Epidemiological Circumstance and Future Prospective. Viruses 2021, 13, 2167. https:/ / doi.org/10.3390/v13112167

Academic Editors: Chao-Nan Lin and Peck Toung Ooi

Received: 25 September 2021

Accepted: 24 October 2021

Published: 27 October 2021

Publisher's Note: MDPI stays neutral with regard to jurisdictional claims in published maps and institutional affiliations.

Copyright: (c) 2021 by the authors. Licensee MDPI, Basel, Switzerland. This article is an open access article distributed under the terms and conditions of the Creative Commons Attribution (CC BY) license (https:/ / creativecommons.org/licenses/by/ $4.0 /)$.
1 The State Key Laboratory of Agricultural Microbiology, Huazhong Agriculture University, Wuhan 430070, China; i.shirani786@yahoo.com (I.S.); ali.dawood@vet.usc.edu.eg (A.D.)

2 College of Veterinary Medicine, Huazhong Agricultural University, Wuhan 430070, China

3 Department of Animal Medicine (Infectious Diseases), Faculty of Veterinary Medicine, Benha University, Toukh 13736, Egypt; abdelfattah.selim@fvtm.bu.edu.eg

4 King Abdulaziz City for Science and Technology, Riyadh 12354, Saudi Arabia; asn1950r@gmail.com

5 The Chair of Vaccines Research for Infectious Diseases, King Saud University, Riyadh 11495, Saudi Arabia; mmalmutairi@ksu.edu.sa

6 Department of Pharmaceutical Technology, Faculty of Pharmacy, Tanta University, Tanta 31111, Egypt; Suleiman.saleh@pharm.tanta.edu.eg

7 Department of Pathology, Faculty of Veterinary Medicine, Benha University, Toukh 13736, Egypt; drsarabadwy@gmail.com

8 Natural Reference Laboratory of Veterinary Drug Residues (HZAU), MAO Key Laboratory for Detection of Veterinary Drug Residues Huazhong Agricultural University, Wuhan 430070, China

9 Para-Clinic Department, Faculty of Veterinary Medicine, Jalalabad 2601, Afghanistan

10 Infectious Diseases, Medicine Department, Faculty of Veterinary Medicine, University of Sadat City, Sadat City 32897, Egypt

11 Hubei International Scientific and Technological Cooperation Base of Veterinary Epidemiology, Huazhong Agricultural University, Wuhan 430070, China

12 Department of Pharmacology and Toxicology, College of Pharmacy, King Saud University, Riyadh 22334, Saudi Arabia

13 College of Sciences and Literature Microbiology, Nothern Border University, Arar 73211, Saudi Arabia; Fahdah1402@hotmail.com

* Correspondence: marawan.adel@fvtm.bu.edu.eg (M.A.M.); aizhen@mail.hzau.edu.cn (A.G.); Abdelfattah.selim@fvtm.bu.edu.eg (A.S.)

Abstract: Bovine leukaemia virus (BLV) is a deltaretrovirus that is closely related to human T-cell leukaemia virus types 1 and 2 (HTLV-1 and -2). It causes enzootic bovine leukosis (EBL), which is the most important neoplastic disease in cattle. Most BLV-infected cattle are asymptomatic, which potentiates extremely high shedding rates of the virus in many cattle populations. Approximately $30 \%$ of them show persistent lymphocytosis that has various clinical outcomes; only a small proportion of animals (less than 5\%) exhibit signs of EBL. BLV causes major economic losses in the cattle industry, especially in dairy farms. Direct costs are due to a decrease in animal productivity and in cow longevity; indirect costs are caused by restrictions that are placed on the import of animals and animal products from infected areas. Most European regions have implemented an efficient eradication programme, yet BLV prevalence remains high worldwide. Control of the disease is not feasible because there is no effective vaccine against it. Therefore, detection and early diagnosis of the disease are essential in order to diminish its spreading and the economic losses it causes. This review comprises an overview of bovine leukosis, which highlights the epidemiology of the disease, diagnostic tests that are used and effective control strategies.

Keywords: bovine leukosis; genome; prevalence; pathogenesis; clinical outcomes; diagnosis; control 


\section{Introduction}

Bovine leukaemia virus (BLV) is a deltaretrovirus that belongs to the Retroviridae family. It is closely related to human T-cell leukaemia virus types 1 and 2 (HTLV-1 and -2) [1,2] and to simian T-cell leukaemia viruses (STLVs). Some of them are also thought to play a role in proliferative or neurological disorders of human and non-human primates $[3,4]$. BLV is the causative agent of enzootic bovine leucosis (EBL), also known as bovine leucosis, which is the most common neoplastic disease of dairy and beef cattle $[1,5,6]$.

Most BLV-infected cattle (about 70\%) are asymptomatic (subclinically infected). Hence, there is an extremely high shedding rate of BLV within cattle populations and its control is rendered unfeasible [7]. About $30 \%$ of BLV-infected cattle develop persistent lymphocytosis $(\mathrm{PL})$ and around $1-5 \%$ may develop tumours in a form of malignant B-cell lymphosarcoma after a long period of latency (one to eight years) [1,8,9].

The immune systems of infected cattle are impaired, even during the latent stages of leukaemia, and this leads to the inability of the animals to maintain normal performance [10]. Therefore, BLV infection results in negative effects on animal health and productivity. The disease causes huge economic losses worldwide through both direct and indirect costs: directly because milk production is reduced, the disease has an extreme impact on reproduction, and some cows must be culled prematurely; and indirectly because imports are restricted of animals from BLV-infected areas [11-15]. For these reasons, the World Organisation for Animal Health (OIE) has listed EBL as a disease that can cause drastic impacts on international trade [16]. For instance, BLV infects more than $40 \%$ of the United States cattle population [17] and annual economic losses have been estimated at USD 525 million from milk loss alone [18,19].

Regarding the public health hazards of bovine leucosis, there is no definitive determination of how humans are infected by BLV or of its effects in infected people. BLV proviral DNA has been found in milk and meat products, which has focused attention on the possible transmission of the disease to humans via such foodstuffs [20]. Several reports show that BLV may harm humans through a possible link between BLV infection and the development of breast cancer in women, as well as other haematopoietic neoplastic diseases [21-25]. Comparison of data indicates a surprising geographical correlation between incidence of breast cancer and the consumption of bovine meat and milk. For example, the UK, Australia, the US, and Germany each have a high prevalence of breast cancer along with high rates of consumption of bovine meat and milk. In contrast, Japan, India, China, and Korea have low rates of consumption of these products and low prevalence of breast cancer $[26,27]$. Thus, prevention and control policies should be established to diminish viral prevalence and transmission rates among cattle populations and to ensure the absence of infected foodstuffs in the market [20].

BLV infection can be diagnosed either by use of serological tests (e.g., through agar gel immunodiffusion (AGID), a radioimmunoprecipitation assay (RIA) or an enzymelinked immunosorbent assay (ELISA)) or by use of proviral DNA detection techniques (e.g., single, semi-nested, nested, or real-time polymerase chain reaction (PCR) tests), which are sensitive and specific methods [16].Vaccination would be effective to control the disease but unfortunately, to date, there is no commercially available vaccine against BLV to prevent EBL because all tested methods have produced only incomplete or transient stimulation of the host immune response [11,28-30]. The most potent, alternative control measure is currently based on the testing of animals and elimination of those that are positive. However, this strategy is not feasible, especially in areas of high BLV prevalence. The aim of this review is to highlight the current epidemiological situation regarding BLV infection and to provide information about some strategies that can be used to fight the disease worldwide, with special reference to some future prospective studies.

\section{BLV Genome}

BLV is a single-strand, diploid RNA virus, the complete genome of which comprises a 8714-nucleotide sequence $[1,31]$. It can be anatomised in the form of (long terminal repeat 
(5'-LTR))-gag-pro-pol-env-px-(long terminal repeat (3'-LTR)) [1,28,32,33]. The $5^{\prime}$ - and $3^{\prime}$-LTRs contain transcriptional promoters for the action of the Tax protein and are composed of three main regions, namely, the U3, R, and U5 regions [34]. Additionally, it has been reported that BLV particle synthesis is accelerated by mutations in the genes of the LTR region and that this acceleration results in a more intense immune response in cattle [35]. The gag gene is highly conserved and consists of a 1178-nucleotide sequence that codes for the polypeptide precursor Pr44, which is subsequently cleaved into three major nonglycosylated proteins (p12 nucleocapsid, p24 capsid, and p15 matrix) by the action of BLV protease [36,37]. The viral protease p14 (pro gene) is encoded by a region located between the gag and pol genes. It is responsible for the post-translational maturation of BLV [38]. The pol gene encodes for reverse transcriptase and integrase enzymes that are responsible for reverse transcription and integration of the BLV proviral DNA into the host genome, which results in life-long infection $[39,40]$.

The env gene is encoded by the polypeptide precursor gpr72, which is cleaved into two glycoproteins, a surface (SU) protein, gp51, and a transmembrane (TM) protein, gp30 [37]. These glycoproteins play an important role in the viral life cycle because they contain the recognition site required for viral entry and they mediate cell fusion [41]. The env gene shows a genetic polymorphism that may be useful in phylogenetic studies and classifications of BLV isolates, as confirmed by several studies [42]. The nucleotide sequence and amino acid composition of the env gene are useful genomic markers of BLV for the study of its distribution and to reveal the presence of different genotypes that correlate with geographic origin [32,43]. Therefore, at least $11 \mathrm{BLV}$ genotypes have been detected through sequencing and phylogenetic analysis of the partial and full-length gp51 env gene. Genotype 1 is the most prevalent, and it and genotype 1 and 3 are common in the US, Japan, and Korea [44]. Genotypes 1, 2, 3, 4, 5, 6, and 9 have been found in South America (genotype 9 particularly in Bolivia). Genotypes 4, 7, and 8 are common in Russia and Eastern Europe. Genotype 10 is prevalent in China, Vietnam, Thailand, and Myanmar [33,45-49]. Genotype 4 was present at some countries from North America, South America, Africa, and Asia [42,50]. Genotype 11 are recorded in China [51] and G6 genotype has been found in South American countries, such as Argentina, Brazil, Peru, Paraguay, and Bolivia [48,52], as well as Asian countries such as the Philippines, Thailand [53], and India [54]. Moreover, genotype 1 was reported in Egypt [55]. Since every new genotype may show unique features of interaction with the host organism and leukaemogenesis is influenced by some genotypes, it is important to monitor the origin of new virus mutations for veterinary and animal husbandry [56,57] (Table 1).

Table 1. BLV Genotyping based on partial BLV env sequences identified in geographical locations around the world.

\begin{tabular}{|c|c|c|c|}
\hline Continent & Countries & Genotype & References \\
\hline \multirow{3}{*}{ Europe } & France & 4 & \multirow{14}{*}[44,50,53,58-64]{} \\
\hline & Belgium & 4 & \\
\hline & Moldova & 7 & \\
\hline \multirow{8}{*}{ Asia } & Korea & $1 \& 3$ & \\
\hline & Japan & $1 \& 2 \& 3$ & \\
\hline & Russia & $4 \& 7 \& 8$ & \\
\hline & Thailand & $1 \& 6 \& 10$ & \\
\hline & Myanmar & $1 \& 6 \& 10$ & \\
\hline & China & $4 \& 6 \& 11$ & \\
\hline & Philippines & $1 \& 6$ & \\
\hline & Iran & 4 & \\
\hline Australia & Australia & 1 & \\
\hline North America & USA & $1 \& 3$ & \\
\hline Central America & Costa Rica & $1 \& 5$ & \\
\hline
\end{tabular}


Table 1. Cont.

\begin{tabular}{ccc}
\hline Continent & Countries & Genotype \\
\hline & Brazil & $1 \& 2 \& 6$ \\
\cline { 2 - 3 } & Uruguay & 1 \\
\cline { 2 - 3 } & Paraguay & $1 \& 6$ \\
\cline { 2 - 3 } & Bolivia & 9 \\
\cline { 2 - 3 } & Argentine & $1 \& 2 \& 4 \& 6$ \\
\hline \multirow{2}{*}{ Africa } & Peru & $1 \& 3 \& 6$ \\
\hline & Colombia & $1 \& 4$ \\
\hline
\end{tabular}

In addition to encoding the previously mentioned essential and structural genes, BLV provirus also encodes additional accessory and regulatory or non-structural genes from the pX region of the genome, which is located between the env gene and the $3^{\prime}$-LTR. Unlike other retroviruses, BLV has an additional tax gene that results from alternative splicing of the $\mathrm{pX}$ region. This additional gene has a crucial role in BLV biology. The Tax protein acts as a trans-activator of BLV provirus transcription and is oncogenic to host cells; it causes their malignant transformation by disturbance of cellular growth and DNA repair inhibition [27]. It also exerts a severe impact on both stress and immune responses [65]. Likewise, the polymorphism of the tax gene is important in the determination of the output of BLV infection; A and $\mathrm{H}$ variants of tax have been found to be correlated with decreased whole-blood counts among BLV-negative animals and, thus, could be the hallmark of the asymptomatic leukosis of BLV infection [66].

In addition to the Tax protein, the pX region also encodes for the rex and the less abundant R3 and G4 proteins. The Rex protein is a post-transcriptional regulator of viral expression that is required for the synthesis of structural genes and is essential for infectivity in vivo [39]. The $R 3$ and G4 genes are infectious and tumourigenic BLV molecular clones that maintain high proviral load; their deletion induces loss of the leukaemogenic phenotype of BLV [67] (Figure 1).

(a)

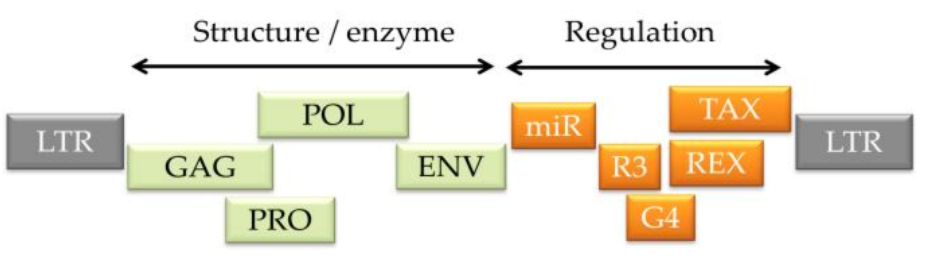

(b)

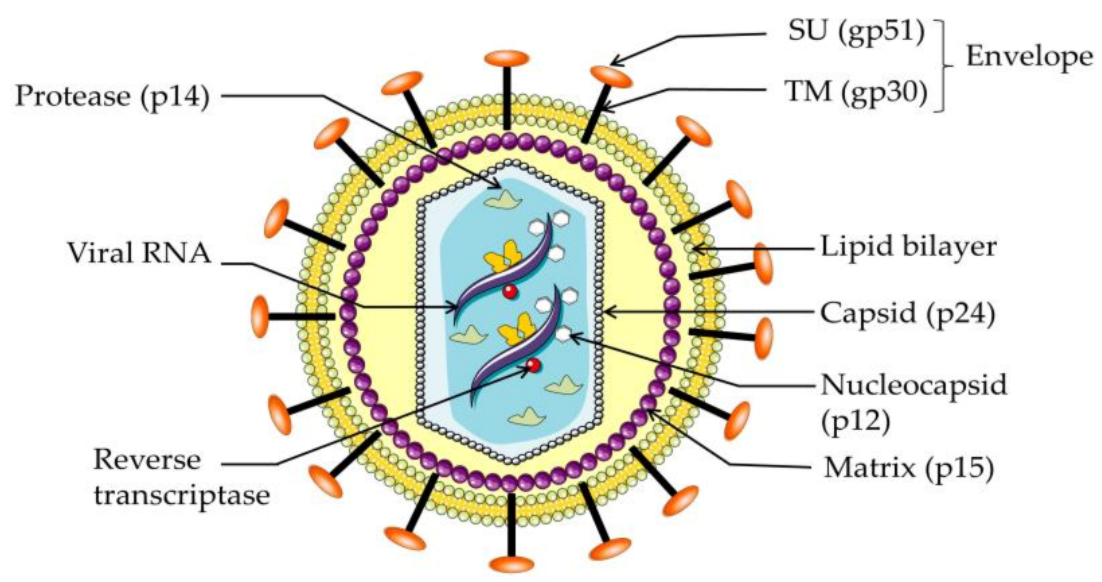

Figure 1. Schematic structure of (a) the bovine leukaemia virus (BLV) genome (b) the viral particle [68]. 
Some researchers have reported that an abundant cluster of RNA polymerase IIItranscribed microRNAs (miRNAs) is expressed even in the absence (silence) of genomic and subgenomic transcripts from the $5^{\prime}$-LTR region [69]. However, recently it has been shown that BLV constitutively expresses antisense transcripts from the $3^{\prime}$-LTR, which may be the reason for the silence of the $5^{\prime}$-LTR region. The BLV miRNAs are not essential for infectivity but have been shown to modify some genes that are related to other mechanisms, such as apoptosis, immunity, cell signalling, and oncogenesis. Moreover, they can be expressed in both cattle that show signs of EBL and asymptomatic leukosis-infected animals [70,71]. The transcriptional interference between antisense and mi-RNAs strongly suggests a common role in BLV regulation and represents a novel pathway for recognition of the disease [72]. The discovery of BLV antisense transcripts, together with the discovery of BLV microRNAs, has resulted in a new understanding of BLV. The BLV provirus produces a large number of viral microRNAs and expresses antisense transcripts in all malignancies studied. The presence of these transcripts in both leukaemic and non-malignant clones suggests that they play an important role in the virus's life cycle and tumourigenic potential [72].

\section{BLV Prevalence}

BLV was first described in 1871 in Lithuania (on the south-eastern shore of the Baltic Sea) [73]. It is now known to be distributed worldwide at different prevalence rates [74]. The US has a very high BLV prevalence rate that has been stated as $40 \%$ [17]. In Japan, EBL was listed as a notifiable disease in 1998. In 2000, it was reported in 159 cattle on 157 farms, and by 2007, in 838 cattle on 677 farms [75]. In 2015, 78\% of 315 dairy herds in Canada showed BLV antibodies [76]. In Argentina, $84 \%$ of dairy herds have been reported to carry the antibodies [58], in Turkey, 2.28\% [77], and in Mexico, between 11\% and $66 \%$ [78]. In China, a meta-analysis study was conducted to measure the prevalence of BLV during the period between 1983 and 2019. It recorded a 10\% pooled BLV prevalence rate (4701 seropositive animals of 34,954 animals) [79]. BLV has also been recorded in some Middle Eastern countries [74]. In Egypt, BLV has been recorded serologically in Egyptian dairy cattle at $15.83 \%$ [80] and at $20.8 \%, 9 \%$, and $0 \%$ in cattle, buffaloes, and camels, respectively.

In contrast, several European regions started to control the virus early in the 1960s; as a result, England, France, Germany, Spain, Belgium, Denmark, Sweden, Switzerland, Poland, and many others are officially free of BLV $[81,82]$. Other countries, such as Italy and Portugal, report extensive BLV-negative localities, and the infection is restricted to small areas. In Australia, the virus has been eliminated from dairy herds, but beef cattle remain infected at very low prevalence rates $[7,83,84]$. More than 21 countries claim to have eradicated BLV, primarily through culling or the segregation of all cattle that have been shown to be positive through ELISA tests $[83,84]$ (Table 2 and Figure 2).

Table 2. Prevalence of the bovine leucosis disease worldwide, adopted from [58].

\begin{tabular}{|c|c|c|c|c|}
\hline Status & Continent & Countries & Year & References \\
\hline \multirow{12}{*}{ BLV free countries } & \multirow{12}{*}{ Europe } & Andorra & 1994 & [85] \\
\hline & & Cyprus & 1995 & [85] \\
\hline & & Czech Republic & 2010 & [85] \\
\hline & & Finland & 2008 & [85] \\
\hline & & Ireland & 1999 & [85] \\
\hline & & Norway & 2002 & [85] \\
\hline & & Spain & 1994 & [85] \\
\hline & & UK & 1996 & [85] \\
\hline & & The Netherlands & 2009 & [86] \\
\hline & & Sweden & 2007 & [85] \\
\hline & & Denmark & 1990 & [85] \\
\hline & & Estonia & 2013 & [85] \\
\hline
\end{tabular}


Table 2. Cont.

\begin{tabular}{|c|c|c|c|c|}
\hline Status & Continent & Countries & Year & References \\
\hline & & Switzerland & 2005 & [85] \\
\hline & & Slovenia & 2006 & [85] \\
\hline & \multirow{3}{*}{ Oceania } & Australia & 2013 & [12] \\
\hline & & New Zealand & 2008 & [87] \\
\hline & & Tunisia & 2005 & [85] \\
\hline & \multirow{2}{*}{ Asia } & Kyrgyzstan & 2008 & [85] \\
\hline & & Kazakhstan & 2007 & [85] \\
\hline \multirow{9}{*}{$\begin{array}{l}\text { BLV existing countries with } \\
\text { unknown prevalence }\end{array}$} & \multirow{8}{*}{ Europe } & Croatia & \multirow{9}{*}{ Present } & {$[86,88]$} \\
\hline & & Ukraine & & [89] \\
\hline & & Italy & & [85] \\
\hline & & Portugal & & [85] \\
\hline & & Belarus & & {$[86,89]$} \\
\hline & & Greece & & [85] \\
\hline & & Bulgaria & & [85] \\
\hline & & Latvia & & [85] \\
\hline & South America & Uruguay & & [90] \\
\hline \multirow{14}{*}{$\begin{array}{l}\text { BLV existing countries with } \\
\text { variable prevalence }\end{array}$} & \multirow{11}{*}{ South America } & $\begin{array}{c}\text { USA } \\
\text { (Dairy } 83.9 \% \text {, Beef 39\%) }\end{array}$ & 2007 & [91] \\
\hline & & $\begin{array}{c}\text { Mexico } \\
\text { (Dairy } 36.1 \% \text {, Beef } 4 \% \text { ) }\end{array}$ & 1983 & [92] \\
\hline & & $\begin{array}{c}\text { Canada } \\
\text { (78\% at herd level) }\end{array}$ & 1998-2003 & [5] \\
\hline & & $\begin{array}{l}\text { Chile (southern regions) } \\
\text { (27.9\% individual level) }\end{array}$ & 2009 & [48] \\
\hline & & $\begin{array}{l}\text { Brazil } \\
17.1 \% \\
60.8 \%\end{array}$ & $\begin{array}{l}1980-1989 \\
1992-1995\end{array}$ & {$[93,94]$} \\
\hline & & $\begin{array}{c}\text { Argentina (Buenos Aires) } \\
\text { (77.4\% at an individual, } 90.9 \% \text { at } \\
\text { herd level) } \\
\text { (Multiple regions) } \\
\text { (32.85\% at individual, } 84 \% \text { at herd } \\
\text { level) }\end{array}$ & $\begin{array}{c}2007 \\
1998-1999\end{array}$ & $\begin{array}{l}{[48]} \\
{[95]}\end{array}$ \\
\hline & & $\begin{array}{c}\text { Peru (Multiple regions) } \\
\text { (31\% at the individual level, } 42.3 \% \\
\text { individual level) }\end{array}$ & $\begin{array}{l}1983 \\
2008\end{array}$ & $\begin{array}{l}{[96]} \\
{[48]}\end{array}$ \\
\hline & & $\begin{array}{l}\text { Bolivia (Multiple regions) } \\
30.7 \% \text { individual level }\end{array}$ & 2008 & [48] \\
\hline & & $\begin{array}{c}\text { Venezuela } \\
33.3 \% \text { individual level }\end{array}$ & 1978 & [97] \\
\hline & & $\begin{array}{l}\text { Paragua (Asuncion) } \\
54.7 \% \text { individual level }\end{array}$ & 2008 & [48] \\
\hline & & $\begin{array}{l}\text { Colombia } \\
62 \% \text { individual level }\end{array}$ & 2020 & [98] \\
\hline & \multirow{3}{*}{ Asia } & $\begin{array}{c}\text { China } \\
\text { (Dairy } 49.1 \% \text {, Beef } 1.6 \% \text { ) }\end{array}$ & 2013-2014 & [99] \\
\hline & & $\begin{array}{c}\text { Taiwan } \\
\begin{array}{c}(81.8 \% \text { at animal level and } 99.1 \% \text { at } \\
\text { herd level })\end{array}\end{array}$ & 2019 & [100] \\
\hline & & $\begin{array}{c}\text { Cambodia } \\
\text { Draught cattle 5.3\% }\end{array}$ & 2000 & [101] \\
\hline
\end{tabular}


Table 2. Cont.

\begin{tabular}{|c|c|c|c|c|}
\hline Status & Continent & Countries & Year & References \\
\hline & & $\begin{array}{c}\text { Japan } \\
\text { (Nationwide) } \\
\text { Dairy } 49.1 \% \text { Beef } 1.6 \% \\
79.1 \% \text { of the dairy herd } \\
73.3 \% \text { at individual }\end{array}$ & $\begin{array}{c}2009-2011 \\
2007 \\
2012-2014\end{array}$ & $\begin{array}{l}{[102]} \\
{[103]} \\
{[104]}\end{array}$ \\
\hline & & Mongolia (Dairy 3.9\%) & 2014 & [105] \\
\hline & & $\begin{array}{l}\text { Iran (nationwide) } \\
(22.1 \% \text { to } 25.4 \%)\end{array}$ & 2012-2014 & [5] \\
\hline & & Philippines ( $4.8 \%$ to $9.7 \%$ ) & 2010-2012 & [106] \\
\hline & & $\begin{array}{c}\text { Myanmar } \\
\text { (9.1\% at individual) }\end{array}$ & 2016 & [48] \\
\hline & & $\begin{array}{c}\text { Thailand } \\
\text { (58.7\% at individual) }\end{array}$ & 2013-2014 & [53] \\
\hline & & Pakistan $(20 \%$ of dairy $)$ & 2019 & [107] \\
\hline & \multirow{5}{*}{ Middle East } & $\begin{array}{l}\text { Saudi Arabia } \\
(20.2 \% \text { of dairy) }\end{array}$ & 1990 & [108] \\
\hline & & $\begin{array}{c}\text { Turkey } \\
\text { (48.3\% dairy) }\end{array}$ & & [109] \\
\hline & & $\begin{array}{c}\text { Israel } \\
(5 \% \text { at individual) }\end{array}$ & & [110] \\
\hline & & Iraq ( $7 \%$ of dairy) & 2015 & [111] \\
\hline & & Egypt (17.7\% of dairy) & 2020 & [112] \\
\hline
\end{tabular}
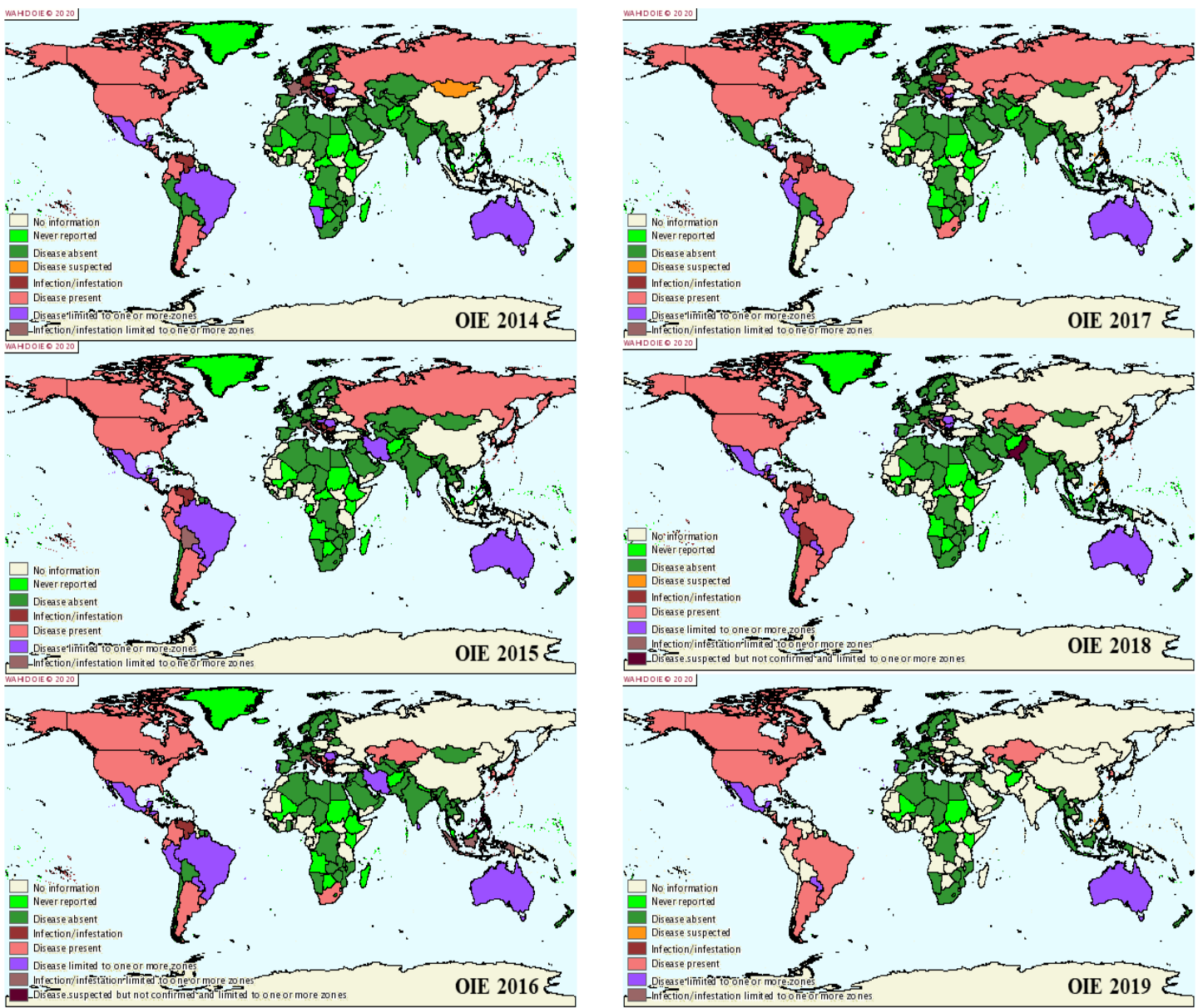

Figure 2. EBL world distribution map based on the last 5 years (2014-2019) [16]. 


\section{BLV Susceptibility}

Generally, retroviruses have a wide host range that includes cattle, buffaloes, sheep, and goats $[113,114]$. Three species are natural hosts of BLV infection:, Bos taurus (domestic cattle), Bos indicus (zebu), and Bubalus bubalis (water buffalo) [15]. The disease is not confirmed in some susceptible species (e.g., capybara, rhesus monkeys, chimpanzees, and antelopes), and has not been detected in other wildlife species, such as deer and llama, under natural conditions $[115,116]$. Experimentally, sheep, goats, pigs, chickens, rats, and rabbits have been infected [117], but the disease has a shorter period of latency, takes over the animal more quickly and is passed on more frequently than in cattle. Rats are one of the suitable models for in vivo studies of BLV infection [118].

Estimates of bovine leucosis inheritability among Holstein and Jersey cattle populations is about $0.08 \%$ [119], which indicates that genetic susceptibility plays a role in the prevalence of BLV in some breeds of cattle [120]. BLV is more frequently spread among dairy than among beef cattle [121]. The intra-herd seroprevalence rates in dairy and beef cattle are reported to be $40.9 \%$ and $28.7 \%$, respectively [102,122]. In China, $49.1 \%$ of dairy and $1.6 \%$ of beef cattle have been found to be BLV-positive [99]. Furthermore, the age of cattle plays a pivotal role in the seroprevalence of BLV, which increases with age until cattle older than two years show seroprevalence rates that are almost twice those found in younger animals [123]. This is because the risk of infection increases as animals spend more time at risk of contact with it [123]. However, EBL has been detected in younger animals; in a two-month-old calf [124], in two calves of around three months of age [125] and in a 13-month-old Holstein heifer [123]. Therefore, more consideration should be given to the possibility of BLV infection regardless of age.

\section{Transmission}

BLV has a harsh transmission dynamic, as the virus exists in circulating peripheral blood lymphocytes of infected animals and the disease can be transmitted by both horizontal and vertical means [126-128]. The critical sources of BLV infection are fresh blood, semen, saliva, milk, and nasal discharges of BLV-seropositive cattle that have PL and that harbour proviral DNA (which enables cell-to-cell transmission) [1,39,127,129,130].

Horizontal or mechanical transmission plays a major role in BLV infection via several potential routes that include all practices performed beyond blood transmission control, such as iatrogenic infection during vaccination, blood extraction, castration, injection of medication, dehorning, tattooing, and rectal palpation [131-133]. Another significant risk for horizontal BLV dissemination is posed by biting flies, such as the stable fly, which can carry the virus from the infected blood of a host animal to a susceptible other during a blood meal and pose a potential risk of infection [40,134]. The crucial role of biting flies in the epidemiology and prevalence of BLV has been identified by two epidemiological studies that were performed in the US and Japan [81]. It was reported that no new cases of EBL were observed in Japanese beef cattle herds after herdsmen implemented rigorous fly control [135-137]. This study showed that passage was via a blood-borne pathogen, such as HTLV-1 or HTLV-2 [1].

A small proportion of BLV infections may occur vertically via the maternal-foetal transmission route from the dam to its foetus or through the ingestion of colostrum and milk that contains provirus or free virus particles. Such transmission has been positively correlated to the proviral loads that have been measured in the dam [138]. Milk cells from BLV-infected cows could cause infection ex vivo, which suggested a potential risk from milk for vertical spread of BLV via cell-to-cell transmission [127]. However, a high antibody titre in the milk and colostrum of BLV-positive dams could protect against BLV infection in vitro [139]. The in utero or transplacental transmission also shares a route of vertical BLV transfer from the dam to her offspring [140]. Therefore, the BLV proviral load and antibody titre in the milk play a direct role in the infection and protection of calves against the disease. 
Artificial insemination (AI) and natural service might also be incriminated in the vertical spread of BLV. Although the risk of in vitro infection with semen from BLV-infected bulls is negligible, the use of infected bulls in natural service has been positively associated with BLV prevalence [141]. Moreover, during natural copulation, the smegma of infected bulls may aid in the transmission of BLV to uninfected cows. So, bulls that are used for natural mating or AI must be screened to ensure that they are BLV-free before the breeding season to aid in the limitation of virus spread [142].

\section{BLV Pathogenesis}

BLV can infect different immune cells that show the highest preferential affinity to B-lymphocytes. It presents in the circulating peripheral blood B lymphocytes of BLVinfected cattle and less often in T-cells $[143,144]$. It disrupts both B- and T-cell homeostasis and alters their proliferative and apoptotic responses as it interferes with gene expression and the actions of signalling cascades at different times post-infection [10]. Cows that develop PL undergo a massive proliferation of B-lymphocytes that express both Ig and $\mathrm{CD}^{+}$antigens on their surface via blockage of their apoptosis rather than triggering of their proliferation [145]. The BLV structural genes pol and env are essential for in vivo infectivity and their deletion eliminates infectivity. Moreover, the polymorphism of the env gene leads to a change in viral pathogenicity [146].

Inactivation of tumour suppressor gene p53 by mutation appears to be one of the critical events that is associated with tumour formation by BLV in cattle but not in sheep [147]. Additionally, sheep show a low level of apoptosis when compared with cattle, because sheep are not natural hosts of BLV; protection against apoptosis at the early asymptomatic stages of the disease seems to result in slower development of leukaemia and reduced pathogenicity [39].

During infection by BLV, a transmembrane glycoprotein of gp51 destabilises the host cell membrane with a fusion peptide, after which the structural proteins enhance viral fusion and infectivity of host cells [148]. Further, it has been noted that mutation of a single envelope N-linked glycosylation site (N $230 \mathrm{E}$ ) of the env gene by conversion of the asparagine codon $(\mathrm{N})$ into glutamic acid (E) enhances the pathogenicity of BLV through enhancement of viral replication, fusogenicity, and protein stability in experimentally infected sheep [41].

After virus entry, there is no detectable viraemia, but there is a strong and persistent humoural immune response to structural proteins, especially against the env gp51 and the major core protein p24 [149]. Synthesis of BLV proviral DNA molecules is achieved by viral reverse transcriptase. Then, with the help of viral integrase, the provirus is inserted at random sites into the host genome in the nucleus of the infected cells [150]. The BLV provirus remains integrated into cellular genomes for life, even in the absence of detectable BLV antibodies, and viral transcription is blocked during the latent period of the disease which is called the silent state [106]. It has been recorded that, when an infected cell with an integrated BLV provirus is transmitted into a new host, the BLV provirus is expressed into viral particles that infect other B lymphocytes [151].

The BLV epitopes have an important influence on the viral life cycle. BLV has three conformational and neutralising epitopes named F, G, and H, which are always found among all BLV strains. This suggests that their presence is essential for viral pathogenesis. Antibodies that are synthesised against epitope $\mathrm{H}$ can prevent cell fusion in culture, while those against epitopes $F$ and $G$ only can reduce the syncytial ability of the virus [152]. Regarding the occurrence of B-cell lymphosarcoma, BLV encodes some miRNAs that are essential for the induction of B-cell tumours and they regulate efficient viral replication in vivo [71]. In this area, the pathogenesis of BLV infection is not fully clear and requires further investigation. 


\section{Clinical Outcomes}

Generally, bovine leucosis takes two forms: the first is a fatal EBL form that is characterised by lymphomas; the second is sporadic bovine leucosis (SBL), which is not transmissible and mainly affects young calves [153]. Furthermore, EBL can be separated into three forms as follows: first, the asymptomatic form, which shows the most frequent occurrence $(70 \%)$ and infected animals appear to be serologically positive without lymphocytosis or any clinical signs; second, the form that causes animals to be serologically positive and positive for PL (30\%). This form causes a non-malignant polyclonal expansion of $\mathrm{CD}^{+} \mathrm{B}$ cells, the majority of which harbour the BLV provirus with high viral load; and the final form exhibits as malignant lymphosarcoma (less than $5 \%$ ). It originates from mono or polyclonal accumulation of $\mathrm{CD}^{+} \mathrm{IgM}^{+} \mathrm{B}$ cells after a long period of latency that may extend to one to eight years, so it is detected at a higher rate in cattle of more than four to five years old rather than in younger animals [58,154-156]. Thus, persistent B-lymphocyte proliferation is the hallmark of BLV-induced leucosis and is referred to as leukaemia in the bloodstream, lymphoma in the lymph node and lymphosarcoma in various organs [147].

The clinical picture of the disease may include the following manifestations: lack of appetite, indigestion, reduced milk yield, chronic bloat, displaced abomasum, diarrhoea, constipation, enlargement of superficial lymph nodes, lameness, paralysis, weight loss, weakness or general debilitation, and sometimes neurological manifestations [106,157].

A field study on BLV-infected cattle in Egypt reported various symptoms, such as lymph node enlargement $(6.25 \%)$, protrusion of conjunctival membrane $(1.67 \%)$, lameness $(0.42 \%)$, emaciation $(1.25 \%)$, and respiratory manifestations as rales and dry cough $(0.83 \%)$ [80]. Cattle with lymphosarcoma almost invariably die, either suddenly or weeks or months after the onset of clinical signs, which differ according to the particular organ(s) involved [158]. The BLV malignancies disrupt the uterus, mesenteric, retro-bulbar, the right auricle of the heart, abomasum, spleen, lung, kidney, urinary tract, spine, and pre-scapular, and sub-iliac lymph nodes [151]. These disruptions result in urinary, respiratory, and digestive disturbances besides other signs according to the organ involved [58].

Recently, it has been speculated that BLV infection decreases the energy production efficiency of cows as it alters the activities of their ruminal and intestinal microbiota, which rely partially on the multiplication ability of BLV strains [159]. Additionally, BLV causes dysfunction of monocytes and neutrophils, which subsequently leads to immunosuppression. Both these effects may explain the elevated susceptibility of the animals to other infections, their reduced milk production and reproductive inefficiency $[160,161]$.

Immunologically, the mechanisms by which BLV immunity is compromised are not clear but several scenarios have been suggested, including (1) disruption of cytokine production and correct immune cell signalling, (2) proliferative and apoptotic disturbance of immune cells, and (3) possible damage caused by activated and infected cells. Therefore, future research on BLV immunology and on how BLV influences response to vaccines and other pathogens is urgently required to calculate the exact economic impact of BLV infection on the cattle industry [10].

\section{Zoonotic Potential of BLV}

The presence of BLV or BLV-infected cells in the milk of most naturally affected cows suggests that humans are frequently exposed to BLV orally [162]. The first indication of BLV's potential impact on public health came from a study conducted in the 1970s, just a few years after the virus was discovered, in which two out of every six chimpanzees fed unpasteurised milk from naturally infected BLV cows developed fatal erythroleukemia [163]. Extensive epidemiological investigations conducted in the United States, Denmark, and Sweden failed to show a link between human leukaemia and bovine leukaemia [164]. Anti-BLV antibodies were not detected in persons with varying levels of BLV exposure in seroepidemiological studies. The lack of BLV-specific sequences in 157 cases of childhood acute lymphoblastic leukaemia or non-lymphoma Hodgkin's and 136 controls in the United States [165], as well as 517 cases of human leukaemia and 162 lung 
cancer patients in Korea [166], provided additional evidence against BLV's involvement in human disease.

Despite the fact that research in the past have revealed a link between BLV and breast cancer, the evidence remains inconclusive. By sensitive enzyme-linked immunosorbent test or PCR, no anti-BLV antibodies or BLV sequences were detected in Chinese healthy or breast cancer patients [167].

Recent studies using more sensitive whole genome sequencing, have found no indication of a link between BLV and human breast cancer. None of the 32 billion sequencing reads collected from 51 breast tumours matched BLV strains [168].

\section{Diagnosis}

To improve recognition of BLV infection and to control its spread, efficient diagnostic techniques should be established for routine and easy application in order to pick out the infected animals. This is why different serological tests are widely used to screen animals for BLV, as shown in Table 3. Although serological tests can provide rapid screening, they are less sensitive than others mentioned earlier and they cannot be adapted for tissue or semen testing [169]. Furthermore, they provide no information regarding the BLV proviral load and the degree of BLV-induced disease progression [170]. They also cannot be used to detect low and transient levels of BLV infection, for which a PCR test can be used (Tables 3 and 4 ).

Table 3. Serological techniques used for diagnosis of BLV prevalence according to the rewarded samples and test sensitivity, reproduced from [58].

\begin{tabular}{|c|c|c|c|c|}
\hline Rewarded Samples & Test & Advantages & Disadvantages & References \\
\hline \multirow{3}{*}{ Serum sample } & $\begin{array}{c}\text { 1. ELISA } \\
\text { (Antibodies p24, gp51) }\end{array}$ & $\begin{array}{l}\text { Sensitive, specific, large } \\
\text { scale screening and rapid }\end{array}$ & $\begin{array}{l}\text { False negatives (cattle in } \\
\text { the early infection phase) } \\
\text { False-positive (maternally } \\
\text { derived antibodies) } \\
\text { Cannot evaluate disease } \\
\text { states of infected cattle. }\end{array}$ & {$[157,170-173]$} \\
\hline & $\begin{array}{c}\text { 2. RIA } \\
\text { (Antibodies p24) }\end{array}$ & $\begin{array}{l}\text { Sensitive Able to detect } \\
\text { BLV during the early } \\
\text { period of infection }\end{array}$ & $\begin{array}{l}\text { Cannot be used for mass } \\
\text { screening }\end{array}$ & {$[174,175]$} \\
\hline & $\begin{array}{c}\text { 3. AGIDT } \\
\text { (Antibodies p24, gp51) }\end{array}$ & $\begin{array}{l}\text { Specific, simple, rapid, } \\
\text { screening and Less } \\
\text { expensive }\end{array}$ & $\begin{array}{c}\text { Less sensitive } \\
\text { Inconclusive } \\
\text { Fail to evaluate disease } \\
\text { states }\end{array}$ & {$[9,171-173]$} \\
\hline Milk and Bulk milk sample & \multicolumn{4}{|c|}{ ELISA [157,170-173] } \\
\hline Virus particle & $\begin{array}{c}\text { PHA } \\
\text { (BLV glycoprotein) }\end{array}$ & $\begin{array}{l}\text { - Sensitive, Specific, } \\
\text { Less expensive, and } \\
\text { Rapid }\end{array}$ & $\begin{array}{l}\text { - } \quad \text { Affected by } \mathrm{pH} \text { and } \\
\text { temperature } \\
\text { - } \quad \text { Hemagglutination } \\
\text { activity reduced by } \\
\text { trypsin and } \\
\text { neuraminidase }\end{array}$ & {$[176]$} \\
\hline
\end{tabular}

Table 4. Molecular techniques used for diagnosis of BLV prevalence according to the rewarded samples and test sensitivity (All detect proviral DNA), adopted from [58].

\begin{tabular}{|c|c|c|c|c|}
\hline Rewarded Samples & Test & Advantages & Disadvantages & References \\
\hline $\begin{array}{c}\text { (Blood, PBMC, Tumour sample, } \\
\text { Buffy coat, Milk, somatic cells, } \\
\text { Semen, Saliva and Nasal } \\
\text { secretions). }\end{array}$ & Realtime PCR & $\begin{array}{l}\text { Direct, fast, sensitive, and } \\
\text { Low risk of contamination. } \\
\text { - } \quad \text { Differentiate EBL from SBL. } \\
\text { Detect BLV during the early } \\
\text { phase of infection or in the } \\
\text { presence of colostrum } \\
\text { antibodies. } \\
\text { - Can detect BLV proviral load. }\end{array}$ & $\begin{array}{l}\text { Needs complicated } \\
\text { sample preparation } \\
\text { Requires specific } \\
\text { primers and probes } \\
\text { Expensive and } \\
\text { Require equipment } \\
\text { (real-time PCR } \\
\text { machine) }\end{array}$ & [170,177-179] \\
\hline
\end{tabular}


Table 4. Cont.

\begin{tabular}{|c|c|c|c|c|}
\hline Rewarded Samples & Test & Advantages & Disadvantages & References \\
\hline & $\begin{array}{l}\text { Conventional PCR } \\
\text { (Single, } \\
\text { Semi-Nested, and } \\
\text { Nested PCR) }\end{array}$ & $\begin{array}{l}\text { Direct, fast, sensitive and can } \\
\text { detect recent infections, } \\
\text { before the development of } \\
\text { antibodies to BLV. } \\
\text { Can be used BLV detection } \\
\text { during the early phase of } \\
\text { infection or in the presence } \\
\text { of colostrum antibodies. }\end{array}$ & $\begin{array}{l}\text { False-negative in } \\
\text { case of low proviral } \\
\text { load and the } \\
\text { presence of PCR } \\
\text { inhibitory } \\
\text { substances in } \\
\text { samples } \\
\text { Ease of } \\
\text { cross-contamination } \\
\text { Requires specific } \\
\text { primers Requires } \\
\text { equipment (PCR } \\
\text { machine) } \\
\text { Needs sequencing } \\
\text { for confirmation }\end{array}$ & $\begin{array}{c}{[157,171,173,180,} \\
181]\end{array}$ \\
\hline Blood only & $\begin{array}{c}\text { Direct blood-based } \\
\text { PCR }\end{array}$ & $\begin{array}{l}\text { - } \\
\text { Applied on the blood } \\
\text { directly without DNA } \\
\text { extraction nor purification } \\
\text { Low risk of contamination }\end{array}$ & $\begin{array}{l}\text { - False-negative in } \\
\text { case of low proviral } \\
\text { load } \\
\text { - less sensitivity }\end{array}$ & {$[11,182,183]$} \\
\hline Blood only & Direct filter PCR & $\begin{array}{l}\text { Novel, rapid, easy, reliable, } \\
\text { and cost-effective diagnostic } \\
\text { test } \\
\text { No need for DNA extraction } \\
\text { Offers simple collection, } \\
\text { transportation, and storage } \\
\text { procedures for clinical blood } \\
\text { specimens }\end{array}$ & $\begin{array}{l}\text { - False-negative in } \\
\text { case of low proviral } \\
\text { load } \\
\text { - less sensitivity }\end{array}$ & [184] \\
\hline
\end{tabular}

Among serological tests, ELISA and AGID are the reference techniques that are recommended by the OIE for diagnosis of BLV infection through the detection of antibodies that are directed to BLV gp51 and p24 proteins. Although AGID is the gold standard, ELISAs have been frequently used due to their higher sensitivity $[39,78,185,186]$. Moreover, in one study, the AGID test failed to detect the infection in up to $30 \%$ of animals that were found by other methods to be positive for BLV [187] and failed to detect BLV-infected animals at a large scale from pooled serum or milk samples, whereas some commercially available ELISAs have been found effective in such cases $[188,189]$ with varying degrees of sensitivity (between 97\% and 100\%) and specificity (between 78\% and 100\%) [186,190].

Compared with serological assays, the development of highly sensitive and more specific molecular techniques, especially those based on different kinds of PCR, has revolutionised the diagnosis of BLV and other viral diseases [191]. So, the detection of BLV proviral DNA is a useful tool to discover whether an animal is BLV-infected or not [192].

PCR tests can detect directly the presence of proviral DNA in BLV-infected cattle that have low, transient, or absent antibody titres. After performance of the PCR, sequencing and phylogenetic analysis enable the study of the distribution of BLV genotypes worldwide. Additionally, a PCR test can be used to differentiate lymphomas that are induced by BLV from those associated with SBL [193]. However, it may fail to detect some cases that are seropositive on ELISA due to the presence of extremely small amounts of provirus genetic material in the lymphocytes of infected animals [194], infection confined to lymphoid tissues rather than circulating lymphocytes [195], or the presence of taq DNA polymerase inhibitors in DNA samples [192].

There are different types of PCR that are useful for different purposes. Each of the conventional single, semi-nested, and nested PCR tests is a useful and sensitive tool that can be used to detect BLV proviral DNA early in blood, organs, or tumour samples, but the 
semi-nested and nested tests provide much higher levels of sensitivity than single PCR, as is summarised in Table 3.

Performance of a single PCR followed by sequencing and phylogenetic analysis of the BLV env, gag, or pol genes, with the interpretation of genotypic clusters of the constructed dendrograms, is the most efficient approach for BLV gene identification and reveals the BLV genetic variations that are found worldwide $[89,196]$. A nested PCR is a specific and reliable method that has various uses: to detect BLV in young calves that have been fed with colostrum from seropositive cows; to differentiate between sporadic and infectious lymphomas (enzootic) in tumour tissues gathered from suspected cases in slaughterhouses, in recent infections before the development of antibodies; as a check when ELISA results are doubtful or show weak positive reactions; and for surveillance of bulls in progeny tests before they are used in AI centres [86].

Another rapid and simple type of PCR is the direct, blood-based PCR system (PCR$\mathrm{DB})$, which was developed to amplify the amount BLV provirus directly from whole blood without DNA extraction and purification. This method is of lower sensitivity than nested PCR but indicates higher specificity and reproducibility, and is cost-effective as it is neither labour-intensive nor time-consuming [11]. Further, a direct filter PCR test has been established recently as a novel, fast, smooth, reliable, and practical diagnostic test that directly detects the BLV proviral DNA in clinical blood samples without DNA extraction while offering simple collection, transportation and storage procedures for clinical blood specimens [184].

Since the proviral load of BLV plays a significant role in both disease progress and prognosis, the need for some molecular techniques to quantify the viral copies in an infected animal became imperative in both diagnosis and eradication strategies of bovine leucosis [182]. A quantitative, real-time PCR for BLV that is based on the SYBR family of dyes is a confirmatory method that shows high sensitivity in the detection of BLV proviral load in infected cattle with low, transient, or undetectable antibody levels during the early stage of infection. Its use is recommended to elucidate the BLV disease status of animals that show uncertain ELISA results in tests of their serum [136,197-200].

A quantitative PCR named the BLV coordination of common motifs qPCR (BLVCoCoMoqPCR) is another highly specific and sensitive diagnostic technique that can be used to detect BLV in specimens that showed negative results in nested PCR tests. It detects various integrated BLV strains within the host genome in clinical cases from a broad geographical origin [170]. This technique can also be used to measure the BLV proviral load of both known and novel BLV variants. Hence, it can be used subsequently to demonstrate the correlation between BLV proviral load and disease progression [201,202].

Luminescence syncytium induction assay (LuSIA) is an easy, highly sensitive and rapid method for identification and quantification of BLV infection. Therefore, it may be effective for high-throughput screening of several samples or for prolonged follow-up surveys. It may also be useful in the detection of BLV-specific antibodies, validation of BLV vaccine candidates, and detection of chemical compounds that are used to treat BLVinfected animals. Thus, LuSIA may be highly beneficial for diagnosis and in the quest to suppress the horizontal spread of BLV [203]. A new, more sensitive, and quantitative protocol for LuSIA to measure BLV infectivity has been established by use of CC81-BLU3G, CC81-GREMG, and CC81-GREMG-CAT1 cells. It is adaptable to several assays including: BLV neutralisation by plasma or serum; screening of anti-viral drugs; and BLV contamination contradiction assay of bovine vaccines. It also can be used to detect both cell-to-cell and cell-free infection of BLV sensitively and at an early time point [204,205].

BLV isolation in cell culture is also an efficient way to detect BLV infection and to study both its viral biology and life cycle. BLV infects a wide range of cell lines derived from various mammalian species and organs; however, the production of viral progeny has been shown to be restricted to some cell lines only [206]. In vitro cultivation of infected polymorph nuclear cells (PBMCs) on foetal bovine lung cells (FBL) or Madin-Darby 
bovine kidney (MDBK) cells leads to viral infection and replication with the production of cytopathic effects (CPE) in a form formation of cell syncytia [207,208].

In addition to the previously mentioned approaches for BLV diagnosis, changes in animals' haemato-biochemical and oxidative status may serve as an indicator of BLV infection. Infection with BLV is associated with a selective reduction in glutathione peroxidase activity without any change in levels of the common plasma oxidative stress markers (i.e., hydroperoxides, conjugated dienes, and malondialdehyde) [209]. The leukaemic lymphocytic cellular infiltration in hepatic and renal tissues promotes disorders of liver and kidney function and impairment of nephron filtration ability because of nephron damage that appears in the early stage of leukosis [210,211]. Therefore, the infection is associated with increased activity of the liver enzymes alanine transaminase, alkaline phosphatase, and aspartate transaminase, and of creatinine and superoxide dismutase. On the other hand, the calcium level is significantly decreased and non-significant alterations have been recorded in levels of malondialdehyde and nitric oxide [212]. BLV infection also significantly affects the haematological parameters of infected animals; BLV-seropositive cattle show significant increases in counts of lymphocytes, leukocytes, monocytes, and neutrophils when compared with seronegative animals. This finding may support the hypothesis that BLV can affect host immune response [213].

\section{Strategies for the Control of BLV Infection}

Programmes to eradicate BLV infection are considered a worldwide challenge. They have never been considered economically feasible, especially when the disease prevalence is high $[14,214]$. Several attempts have been made to control BLV infection and to decrease the disease frequency in the herds, especially for multiparous cows with $\geq 5$ parities that live on large farms with more than 200 cows, since these are considered to be among the main risk factors [112].

Four main strategies can be followed to prevent BLV infection: test and cull, genetic selection, good management practice, and vaccination. Several European regions where BLV prevalence is low successfully implement a policy to test all animals and cull those that are found to be positive alongside ongoing surveillance for the evidence of disease [18]. Regions with high prevalence rates should reduce these rates to a point at which test and cull is economically feasible [18]. This strategy involves periodic screening through use of ELISA, PCR-DB, and real-time PCR followed by segregation of all positive cases and of animals that exhibit high proviral load (more than three BLV copies/100 cells) at intervals of several months or a few years $[11,88,182]$. Additionally, the culling of older cows with high whole blood and lymphocyte counts helps to control BLV infection and is considered the cheapest screening method as it avoids the need for further testing $[215,216]$.

Eradication of BLV infection could also be achieved through genetic selection of animals that carry resistance genes in their major histocompatibility complex class II molecules, because cattle with the BoLA class II DRB3 * 0902 allele have been found to be BLV-resistant or to show significantly low levels of BLV proviral load. However, such a strategy could have critical drawbacks regarding the susceptibility of the genetically selected animals to other fatal diseases in the future [2,217].

Disease prevalence can also be reduced by application of safety procedures, such as introduction of an appropriate quarantine period when cattle arrive on a farm and serological testing against BLV antibodies alongside use of a closed trading system that avoids the introduction of animals from infected localities. Focus on the between-farm movement of animals is crucial [218]. Traditional management practices are recommended for the control of BLV transmission, including: the single use of hypodermic needles and reproductive examination sleeves; use of AI instead of natural breeding; control of biting arthropods; feeding calves only heat-treated colostrum or colostrum replacements; and the cleaning and disinfection of blood-contaminated equipment that is reused during surgical operations, such as application of ear tags, tattooing, and dehorning through use of chloroform, ether, and UV. Application of all these practices might eventually reduce 
the prevalence of BLV-infected cattle to a sufficiently low level to introduce a test and cull policy $[39,219]$. Moreover, vertical disease spread can be avoided by the freezing and thawing of the colostrum and milk (at $-25^{\circ} \mathrm{C}$ for one night followed by thawing) before feeding calves. This system could be used by veterinarians and farmers in the development of an effective BLV control programme [220].

As with other viral diseases, a vaccination programme is urgently required to control BLV infection, and a vaccine against bovine leucosis is in great demand. However, individual differences in sensitivity to the disease make it difficult to assess the efficiency of a candidate vaccine [221]. Several epitopes have been obtained from gp51, gp30, and Tax, and this work has demonstrated that these proteins are heavily involved in development of cellular immunity. The gp51p16-C and CD8+CTL epitopes from gp30 and Tax proteins are particularly beneficial to provide a potent target for BLV monoclonal antibody production. They may greatly facilitate the development of therapeutic and prophylactic strategies for BLV [222,223]. Efficient, safe BLV vaccine has been produced through use of recombinant vaccines that are vectored by lumpy skin disease virus (LSDV) against both BLV and LSDV. Expression of the BLV env and gag antigens from the recombinant vaccine was confirmed [224].

Despite trials of vaccines against BLV, there is no effective therapy or commercial vaccine yet available for the control of EBL, mainly because trials show only an incomplete or transient stimulation of the host immune response [11,225].

\section{Conclusions}

Bovine leucosis is an important disease that affects the economy of localities in which it is endemic through its withering effect on the animal, either directly or indirectly. The most successful means for its eradication is the testing and culling of infected animals with the implementation of a closed trading system that prevents the introduction of new animals from infected areas. Such a system is followed by most European countries. Control of EBL at the national level usually involves one or more of the following four approaches: test and segregation or test and slaughter; genetic selection; management interventions; and development of a novel efficient vaccine.

\section{Future Prospective Studies}

Based on the previously reported data, the need for an innovative BLV vaccine has become critical. Therefore, research should be directed toward the development of a novel marker BLV vaccine that omits single or multiple genes related to viral immunosuppression or virulence. Introduction of such a vaccine would reduce BLV prevalence rates worldwide to controllable levels. Then, a test and cull strategy should be implemented. Both together may offer a way to eradicate the disease at the global level. Furthermore, BLV proteomic analysis should be considered, as knowledge of the protein composition of BLV would increase understanding of important characteristics, such as how the virus interacts with host cells. Such understanding would subsequently lead to valuable knowledge for the elucidation of viral biologies, such as replication, tropism, virulence, and immunogenicity.

Author Contributions: Writing—original draft preparation, M.A.M., A.S. and S.B.; writing—review and editing, M.A.M., A.S., S.E.T., I.S., A.A., M.M.A., F.A.A. and A.D.; supervision, A.G.; Funding acquisition, A.G.; Project administration, A.G. All authors have read and agreed to the published version of the manuscript.

Funding: This study was supported by China Agriculture Research System (Beef/Yaks) of MOF and MARA (CARS-37) and the Key Research and Development Program of the Ningxia Hui Autonomous Region (\#.2021BEF02028).

Institutional Review Board Statement: Not applicable.

Informed Consent Statement: Not applicable.

Data Availability Statement: Data sharing not applicable. 
Conflicts of Interest: The authors declare no conflict of interest.

\section{References}

1. Aida, Y.; Murakami, H.; Takagashi, M.; Takeshima, S.-N. Mechanisms of pathogenesis induced by bovine leukemia virus as a model for human T-cell leukemia virus. Front. Microbiol. 2013, 4, 328. [CrossRef]

2. Brujeni, G.N.; Ghorbanpour, R.; Esmailnejad, A. Association of BoLA-DRB3. 2 alleles with BLV infection profiles (persistent lymphocytosis/lymphosarcoma) and lymphocyte subsets in Iranian Holstein cattle. Biochem. Genet. 2016, 54, 194-207. [CrossRef] [PubMed]

3. Maclachlan, N.J.; Dubovi, E.J. Fenner's Veterinary Virology; Academic Press: Cambridge, MA, USA, 2010.

4. Martin, F.; Bangham, C.R.; Ciminale, V.; Lairmore, M.D.; Murphy, E.L.; Switzer, W.M.; Mahieux, R. Conference highlights of the 15th international conference on human retrovirology: HTLV and related retroviruses, 4-8 june 2011, Leuven, Gembloux, Belgium. Retrovirology 2011, 8, 1-15. [CrossRef] [PubMed]

5. Nekouei, O.; Stryhn, H.; VanLeeuwen, J.; Kelton, D.; Hanna, P.; Keefe, G. Predicting within-herd prevalence of infection with bovine leukemia virus using bulk-tank milk antibody levels. Prev. Vet. Med. 2015, 122, 53-60. [CrossRef]

6. Moratorio, G.; Fischer, S.; Bianchi, S.; Tomé, L.; Rama, G.; Obal, G.; Carrión, F.; Pritsch, O.; Cristina, J. A detailed molecular analysis of complete Bovine Leukemia Virus genomes isolated from B-cell lymphosarcomas. Vet. Res. 2013, 44, 19. [CrossRef]

7. Juliarena, M.A.; Barrios, C.N.; Lützelschwab, C.M.; Esteban, E.N.; Gutiérrez, S.E. Bovine Leukemia Virus: Current Perspectives; Dove Press: Manchester, UK, 2017.

8. Pandey, G.S.; Simulundu, E.; Mwiinga, D.; Samui, K.L.; Mweene, A.S.; Kajihara, M.; Mangani, A.; Mwenda, R.; Ndebe, J.; Konnai, S. Clinical and subclinical bovine leukemia virus infection in a dairy cattle herd in Zambia. Arch. Virol. 2017, 162, 1051-1056. [CrossRef] [PubMed]

9. $\quad$ Aida, Y.; Miyasaka, M.; Okada, K.; Onuma, M.; Kogure, S.; Suzuki, M.; Minoprio, P.; Levy, D.; Ikawa, Y. Further phenotypic characterization of target cells for bovine leukemia virus experimental infection in sheep. Am. J. Vet. Res. 1989, 50, $1946-1951$. [PubMed]

10. Frie, M.C.; Coussens, P.M. Bovine leukemia virus: A major silent threat to proper immune responses in cattle. Vet. Immunol. Immunopathol. 2015, 163, 103-114. [CrossRef]

11. Nishimori, A.; Konnai, S.; Ikebuchi, R.; Okagawa, T.; Nakahara, A.; Murata, S.; Ohashi, K. Direct polymerase chain reaction from blood and tissue samples for rapid diagnosis of bovine leukemia virus infection. J. Vet. Med. Sci. 2016, 78, 791-796. [CrossRef]

12. Panel, E.A. Scientific opinion on enzootic bovine leukosis. EFSA J. 2015, 13, 4188.

13. Erskine, R.; Bartlett, P.; Byrem, T.; Render, C.; Febvay, C.; Houseman, J. Association between bovine leukemia virus, production, and population age in Michigan dairy herds. J. Dairy Sci. 2012, 95, 727-734. [CrossRef]

14. Norby, B.; Bartlett, P.; Byrem, T.; Erskine, R. Effect of infection with bovine leukemia virus on milk production in Michigan dairy cows. J. Dairy Sci. 2016, 99, 2043-2052. [CrossRef] [PubMed]

15. Manaa, E.; Marawan, M.; Abdelhady, A.; Selim, A. Association between bovine leukemia virus infection, reproductive performance and milk production in water buffaloes and dairy cattle in Egypt. Adv. Anim. Vet. Sci. 2020, 8, 1109-1113. [CrossRef]

16. OIE. Enzootic bovine leukosis. In Manual of Diagnostic Tests and Vaccines for Terrestrial Animals; World Organisation for Animal Health: Paris, France, 2018; pp. 1113-1124. Available online: https://www.oie.int/standard-setting/terrestrial-manual/access-online/ (accessed on 11 August 2020).

17. LaDronka, R.M.; Ainsworth, S.; Wilkins, M.J.; Norby, B.; Byrem, T.M.; Bartlett, P.C. Prevalence of bovine leukemia virus antibodies in US dairy cattle. Vet. Med. Int. 2018, 2018, 5831278. [CrossRef]

18. Ruggiero, V.; Norby, B.; Benitez, O.; Hutchinson, H.; Sporer, K.; Droscha, C.; Swenson, C.; Bartlett, P. Controlling bovine leukemia virus in dairy herds by identifying and removing cows with the highest proviral load and lymphocyte counts. J. Dairy Sci. 2019, 102, 9165-9175. [CrossRef] [PubMed]

19. Ott, S.L.; Johnson, R.; Wells, S.J. Association between bovine-leukosis virus seroprevalence and herd-level productivity on US dairy farms. Prev. Vet. Med. 2003, 61, 249-262. [CrossRef]

20. Olaya-Galan, N.; Corredor-Figueroa, A.; Guzman-Garzon, T.; Rios-Hernandez, K.; Salas-Cardenas, S.; Patarroyo, M.; Gutierrez, M. Bovine leukaemia virus DNA in fresh milk and raw beef for human consumption. Epidemiol. Infect. 2017, 145, 3125-3130. [CrossRef]

21. Buehring, G.C.; Shen, H.M.; Jensen, H.M.; Choi, K.Y.; Sun, D.; Nuovo, G. Bovine leukemia virus DNA in human breast tissue. Emerg. Infect. Dis. 2014, 20, 772. [CrossRef]

22. Buehring, G.C.; Shen, H.M.; Jensen, H.M.; Jin, D.L.; Hudes, M.; Block, G. Exposure to bovine leukemia virus is associated with breast cancer: A case-control study. PLoS ONE 2015, 10, e0134304. [CrossRef]

23. Giovanna, M.; Carlos, U.J.; María, U.A.; Gutierrez, M.F. Bovine Leukemia Virus Gene Segment Detected in Human Breast Tissue. Open J. Med. J. 2013, 3, 28694. [CrossRef]

24. Buehring, G.C.; Shen, H.; Schwartz, D.A.; Lawson, J.S. Bovine leukemia virus linked to breast cancer in Australian women and identified before breast cancer development. PLoS ONE 2017, 12, e0179367. [CrossRef]

25. Olaya-Galán, N.N.; Salas-Cárdenas, S.P.; Rodriguez-Sarmiento, J.L.; Ibáñez-Pinilla, M.; Monroy, R.; Corredor-Figueroa, A.P.; Rubiano, W.; de la Peña, J.; Shen, H.; Buehring, G.C. Risk factor for breast cancer development under exposure to bovine leukemia virus in Colombian women: A case-control study. PLOS ONE 2021, 16, e0257492. [CrossRef] [PubMed] 
26. Zur Hausen, H.; de Villiers, E.M. Dairy cattle serum and milk factors contributing to the risk of colon and breast cancers. Int. J. Cancer 2015, 137, 959-967. [CrossRef] [PubMed]

27. Lawson, J.S.; Salmons, B.; Glenn, W.K. Oncogenic Viruses and Breast Cancer: Mouse Mammary Tumor Virus (MMTV), Bovine Leukemia Virus (BLV), Human Papilloma Virus (HPV), and Epstein-Barr Virus (EBV). Front. Oncol. 2018, 8, 1. [CrossRef]

28. Boris-Lawrie, K.; Altanerova, V.; Altaner, C.; Kucerova, L.; Temin, H.M. In vivo study of genetically simplified bovine leukemia virus derivatives that lack tax and rex. J. Virol. 1997, 71, 1514-1520. [CrossRef]

29. Pătraşcu, I.; Coman, S.; Sandu, I.; Stiube, P.; Munteanu, I.; Coman, T.; Ionescu, M.; Popescu, D.; Mihăilescu, D. Specific protection against bovine leukemia virus infection conferred on cattle by the Romanian inactivated vaccine BL-VACC-RO. Virologie 1980, 31, 95-102.

30. Ristau, E.; Beier, D.; Wittmann, W.; Klima, F. Protection of sheep against infection with bovine leukemia virus by vaccination with tumor cells or tumor cell preparations from lymph nodes of leukemic cattle. Arch. Exp. Vet. 1987, 41, 185-196.

31. Sagata, N.; Yasunaga, T.; Ohishi, K.; Tsuzuku-Kawamura, J.; Onuma, M.; Ikawa, Y. Comparison of the entire genomes of bovine leukemia virus and human T-cell leukemia virus and characterization of their unidentified open reading frames. $E M B O J$. 1984, 3, 3231-3237. [CrossRef]

32. Zhao, X.; Buehring, G.C. Natural genetic variations in bovine leukemia virus envelope gene: Possible effects of selection and escape. Virology 2007, 366, 150-165. [CrossRef]

33. Donnik, I. Productivity and health markers for large cattle. Int. J. Green Pharm. (IJGP) 2017, 11, S620-S625.

34. Derse, D. Bovine leukemia virus transcription is controlled by a virus-encoded trans-acting factor and by cis-acting response elements. J. Virol. 1987, 61, 2462-2471. [CrossRef]

35. Blazhko, N.; Vyshegurov, S.K.; Donchenko, A.; Shatokhin, K.; Krytsyna, T.; Ryabinina, V. Association of haplotypes for SNPs in the LTR regions of bovine leukemia virus with hematological indices of cattle. Vavilov J. Genet. Breed. 2019, 23, 162-169. [CrossRef]

36. Katoh, I.; Kyushiki, H.; Sakamoto, Y.; Ikawa, Y.; Yoshinaka, Y. Bovine leukemia virus matrix-associated protein MA (p15): Further processing and formation of a specific complex with the dimer of the $5^{\prime}$-terminal genomic RNA fragment. J. Virol. 1991, 65, 6845-6855. [CrossRef] [PubMed]

37. Mamoun, R.; Morisson, M.; Rebeyrotte, N.; Busetta, B.; Couez, D.; Kettmann, R.; Guillemain, B. Sequence variability of bovine leukemia virus env gene and its relevance to the structure and antigenicity of the glycoproteins. J. Virol. 1990, 64, 4180-4188 [CrossRef] [PubMed]

38. Llames, L.; Goyache, J.; Domenech, A.; Montaña, A.V.; Suarez, G.; Gomez-Lucia, E. Cellular distribution of bovine leukemia virus proteins gp51SU, Pr72env, and Pr66gag-pro in persistently infected cells. Virus Res. 2001, 79, 47-57. [CrossRef]

39. Camargos, M.F.; Reis, J.K.; Leite, R.C. Bovine leukemia virus. Virus Rev. Res. 2004, 9, 44-59. [CrossRef]

40. Lairmore, M.D. Animal models of bovine leukemia virus and human T-lymphotrophic virus type-1: Insights in transmission and pathogenesis. Annu. Rev. Anim. Biosci. 2014, 2, 189-208. [CrossRef]

41. De Brogniez, A.; Bouzar, A.B.; Jacques, J.-R.; Cosse, J.-P.; Gillet, N.; Callebaut, I.; Reichert, M.; Willems, L. Mutation of a single envelope N-linked glycosylation site enhances the pathogenicity of bovine leukemia virus. J. Virol. 2015, 89, 8945-8956. [CrossRef]

42. Rola-Łuszczak, M.; Sakhawat, A.; Pluta, A.; Ryło, A.; Bomba, A.; Bibi, N.; Kuźmak, J. Molecular Characterization of the env Gene of Bovine Leukemia Virus in Cattle from Pakistan with NGS-Based Evidence of Virus Heterogeneity. Pathogens 2021, 10, 910. [CrossRef]

43. Licursi, M.; Inoshima, Y.; Wu, D.; Yokoyama, T.; González, E.T.; Sentsui, H. Provirus variants of bovine leukemia virus in naturally infected cattle from Argentina and Japan. Vet. Microbiol. 2003, 96, 17-23. [CrossRef]

44. Lee, E.; Kim, E.-J.; Joung, H.-K.; Kim, B.-H.; Song, J.-Y.; Cho, I.-S.; Lee, K.-K.; Shin, Y.-K. Sequencing and phylogenetic analysis of the gp51 gene from Korean bovine leukemia virus isolates. Virol. J. 2015, 12, 1-13. [CrossRef] [PubMed]

45. Kim, Y.-H.; Lee, E.-Y.; Oem, J.-K.; Kim, S.-H.; Lee, M.-H.; Lee, K.-K.; Park, S.-C. Genetic Analysis of Env and Gag Gene Fragments of Bovine Leukemia Virus Identified in Cattle from Korea. Korean J.Vet. Res. 2015, 55, 53-56. [CrossRef]

46. Marawan, M.A.; Mekata, H.; Hayashi, T.; Sekiguchi, S.; Kirino, Y.; Horii, Y.; Moustafa, A.-M.M.; Arnaout, F.K.; Galila, E.S.M.; Norimine, J. Phylogenetic analysis of env gene of bovine leukemia virus strains spread in Miyazaki prefecture, Japan. J. Vet. Med. Sci. 2017, 79, 912-916. [CrossRef] [PubMed]

47. Pluta, A.; Rola-Łuszczak, M.; Kubiś, P.; Balov, S.; Moskalik, R.; Choudhury, B.; Kuźmak, J. Molecular characterization of bovine leukemia virus from Moldovan dairy cattle. Arch. Virol. 2017, 162, 1563-1576. [CrossRef]

48. Polat, M.; Takeshima, S.-N.; Hosomichi, K.; Kim, J.; Miyasaka, T.; Yamada, K.; Arainga, M.; Murakami, T.; Matsumoto, Y.; Diaz, V.B. A new genotype of bovine leukemia virus in South America identified by NGS-based whole genome sequencing and molecular evolutionary genetic analysis. Retrovirology 2016, 13, 4. [CrossRef] [PubMed]

49. Le, D.T.; Yamashita-Kawanishi, N.; Okamoto, M.; Nguyen, S.V.; Nguyen, N.H.; Sugiura, K.; Miura, T.; Haga, T. Detection and genotyping of bovine leukemia virus (BLV) in Vietnamese cattle. J. Vet. Med. Sci. 2020, 82, 1042-1050. [CrossRef] [PubMed]

50. Hamada, R.; Metwally, S.; Polat, M.; Borjigin, L.; Ali, A.O.; Abdel-Hady, A.; Mohamed, A.E.; Wada, S.; Aida, Y. Detection and molecular characterization of bovine leukemia virus in Egyptian dairy cattle. Front. Vet. Sci. 2020, 7, 608. [CrossRef]

51. Yu, C.; Wang, X.; Zhou, Y.; Wang, Y.; Zhang, X.; Zheng, Y. Genotyping bovine leukemia virus in dairy cattle of Heilongjiang, northeastern China. BMC Vet. Res. 2019, 15, 179. [CrossRef] [PubMed]

52. Rodriguez, S.M.; Golemba, M.D.; Campos, R.H.; Trono, K.; Jones, L.R. Bovine leukemia virus can be classified into seven genotypes: Evidence for the existence of two novel clades. J. Gen. Virol. 2009, 90, 2788-2797. [CrossRef] 
53. Lee, E.; Kim, E.J.; Ratthanophart, J.; Vitoonpong, R.; Kim, B.H.; Cho, I.S.; Song, J.Y.; Lee, K.K.; Shin, Y.K. Molecular epidemiological and serological studies of bovine leukemia virus (BLV) infection in Thailand cattle. Infect. Genet. Evol. 2016, 41, 245-254. [CrossRef]

54. Gautam, S.; Mishra, N.; Kalaiyarasu, S.; Jhade, S.K.; Sood, R. Molecular characterization of bovine leukaemia virus (BLV) strains reveals existence of genotype 6 in cattle in India with evidence of a new subgenotype. Transbound Emerg. Dis. 2018, 65, 1968-1978. [CrossRef] [PubMed]

55. Selim, A.; Manaa, E.; Alanazi, A.; Alyousif, M. Seroprevalence, Risk Factors and Molecular Identification of Bovine Leukemia Virus in Egyptian Cattle. Animals 2021, 11, 319. [CrossRef]

56. Fenner, F.J.; Bachmann, P.A.; Gibbs, E.P.J. Veterinary Virology; Academic Press: Cambridge, MA, USA, 2014.

57. Inoue, E.; Matsumura, K.; Maekawa, K.; Nagatsuka, K.; Nobuta, M.; Hirata, M.; Minagawa, A.; Osawa, Y.; Okazaki, K. Genetic heterogeneity among bovine leukemia viruses in Japan and their relationship to leukemogenicity. Arch. Virol. 2011, 156, 1137-1141. [CrossRef]

58. Polat, M.; Takeshima, S.-N.; Aida, Y. Epidemiology and genetic diversity of bovine leukemia virus. Virol. J. 2017, 14, 209. [CrossRef] [PubMed]

59. Yang, Y.; Chen, L.; Dong, M.; Huang, W.; Hao, X.; Peng, Y.; Gong, Z.; Qin, A.; Shang, S.; Yang, Z. Molecular characterization of bovine leukemia virus reveals existence of genotype 4 in Chinese dairy cattle. Virol. J. 2019, 16, 1-7. [CrossRef]

60. Phiri, M.M.; Kaimoyo, E.; Changula, K.; Silwamba, I.; Chambaro, H.M.; Kapila, P.; Kajihara, M.; Simuunza, M.; Muma, J.B.; Pandey, G.S. Molecular detection and characterization of genotype 1 bovine leukemia virus from beef cattle in the traditional sector in Zambia. Arch. Virol. 2019, 164, 2531-2536. [CrossRef]

61. Kazemimanesh, M.; Madadgar, O.; Steinbach, F.; Choudhury, B.; Azadmanesh, K. Detection and molecular characterization of bovine leukemia virus in various regions of Iran. J. Gen. Virol. 2019, 100, 1315-1327. [CrossRef] [PubMed]

62. Suzuki, A.; Chapman, R.; Douglass, N.; Carulei, O.; van Rensburg, J.; Williamson, A.-L. Phylogenetic Analysis of South African Bovine Leukaemia Virus (BLV) Isolates. Viruses 2020, 12, 898. [CrossRef]

63. Úsuga-Monroy, C.; Díaz, F.J.; Echeverri-Zuluaga, J.J.; González-Herrera, L.G.; López-Herrera, A. Presence of bovine leukemia virus genotypes 1 and 3 in Antioquia, Colombia. Rev. UDCA Actual. Divulg. Científica 2018, 21, 119-126.

64. Moe, K.K.; Polat, M.; Borjigin, L.; Matsuura, R.; Hein, S.T.; Moe, H.H.; Aida, Y. New evidence of bovine leukemia virus circulating in Myanmar cattle through epidemiological and molecular characterization. PLoS ONE 2020, 15, e0229126. [CrossRef] [PubMed]

65. Arainga, M.; Takeda, E.; Aida, Y. Identification of bovine leukemia virus tax function associated with host cell transcription, signaling, stress response and immune response pathway by microarray-based gene expression analysis. BMC Genom. 2012, 13, 121. [CrossRef] [PubMed]

66. Zyrianova, I.M.; Kovalchuk, S.N. Bovine leukemia virus tax gene/Tax protein polymorphism and its relation to Enzootic Bovine Leukosis. Virulence 2020, 11, 80-87. [CrossRef]

67. Kerkhofs, P.; Heremans, H.; Burny, A.; Kettmann, R.; Willems, L. In vitro and in vivo oncogenic potential of bovine leukemia virus G4 protein. J. Virol. 1998, 72, 2554-2559. [CrossRef] [PubMed]

68. Barez, P.-Y.; De Brogniez, A.; Carpentier, A.; Gazon, H.; Gillet, N.; Gutiérrez, G.; Hamaidia, M.; Jacques, J.-R.; Perike, S.; Sriramareddy, S.N. Recent advances in BLV research. Viruses 2015, 7, 6080-6088. [CrossRef]

69. Kincaid, R.P.; Burke, J.M.; Sullivan, C.S. RNA virus microRNA that mimics a B-cell oncomiR. Proc. Natl. Acad. Sci. USA 2012, 109, 3077-3082. [CrossRef] [PubMed]

70. Rosewick, N.; Momont, M.; Durkin, K.; Takeda, H.; Caiment, F.; Cleuter, Y.; Vernin, C.; Mortreux, F.; Wattel, E.; Burny, A. Deep sequencing reveals abundant noncanonical retroviral microRNAs in B-cell leukemia/lymphoma. Proc. Natl. Acad. Sci. USA 2013, 110, 2306-2311. [CrossRef] [PubMed]

71. Gillet, N.A.; Hamaidia, M.; De Brogniez, A.; Gutierrez, G.; Renotte, N.; Reichert, M.; Trono, K.; Willems, L. Bovine leukemia virus small noncoding RNAs are functional elements that regulate replication and contribute to oncogenesis in vivo. PLoS Pathog. 2016, 12, e1005588. [CrossRef]

72. Durkin, K.; Rosewick, N.; Artesi, M.; Hahaut, V.; Griebel, P.; Arsic, N.; Burny, A.; Georges, M.; Van den Broeke, A. Characterization of novel Bovine Leukemia Virus (BLV) antisense transcripts by deep sequencing reveals constitutive expression in tumors and transcriptional interaction with viral microRNAs. Retrovirology 2016, 13, 1-16. [CrossRef]

73. Burng, A. Bovine leukemia virus: Molecular biology and epidemiology. Viral Oncol. 1980, 1980, 231-289.

74. Rodríguez, S.M.; Florins, A.; Gillet, N.; De Brogniez, A.; Sánchez-Alcaraz, M.T.; Boxus, M.; Boulanger, F.; Gutiérrez, G.; Trono, K.; Alvarez, I. Preventive and therapeutic strategies for bovine leukemia virus: Lessons for HTLV. Viruses 2011, 3, 1210-1248. [CrossRef]

75. MAFF. The National Animal Health Statistics; MAFF: Tokyo, Japan, 2011. (In Japanese)

76. Nekouei, O.; VanLeeuwen, J.; Sanchez, J.; Kelton, D.; Tiwari, A.; Keefe, G. Herd-level risk factors for infection with bovine leukemia virus in Canadian dairy herds. Prev. Vet. Med. 2015, 119, 105-113. [CrossRef]

77. Şevik, M.; Avc1, O.; İnce, Ö.B. An 8-year longitudinal sero-epidemiological study of bovine leukaemia virus (BLV) infection in dairy cattle in Turkey and analysis of risk factors associated with BLV seropositivity. Trop. Anim. Health Prod. 2015, 47, 715-720. [CrossRef]

78. Heinecke, N.; Tórtora, J.; Martínez, H.A.; Gonzalez-Fernandez, V.D.; Ramírez, H. Detection and genotyping of bovine leukemia virus in Mexican cattle. Arch. Virol. 2017, 162, 3191-3196. [CrossRef] [PubMed] 
79. Ma, B.-Y.; Gong, Q.-L.; Sheng, C.-Y.; Liu, Y.; Ge, G.-Y.; Li, D.-L.; Diao, N.-C.; Shi, K.; Li, J.-M.; Sun, Z.-B. Prevalence of bovine leukemia in 1983-2019 in China: A systematic review and meta-analysis. Microb. Pathog. 2020, 2020, 104681.

80. Zaher, K.S.; Ahmed, W.M. Bovine leukemia virus infection in dairy cows in Egypt. Acad. J. Cancer Res. 2014, 7, 126-130.

81. Bartlett, P.C.; Sordillo, L.M.; Byrem, T.M.; Norby, B.; Grooms, D.L.; Swenson, C.L.; Zalucha, J.; Erskine, R.J. Options for the control of bovine leukemia virus in dairy cattle. J. Am. Vet. Med. Assoc. 2014, 244, 914-922. [CrossRef]

82. Whittington, R.; Donat, K.; Weber, M.F.; Kelton, D.; Nielsen, S.S.; Eisenberg, S.; Arrigoni, N.; Juste, R.; Sáez, J.L.; Dhand, N. Control of paratuberculosis: Who, why and how. A review of 48 countries. BMC Vet. Res. 2019, 15, 198. [CrossRef]

83. Ruggiero, V.J.; Bartlett, P.C. Control of bovine leukemia virus in three US dairy herds by culling ELISA-positive cows. Vet. Med. Int. 2019, 2019, 3202184. [CrossRef] [PubMed]

84. More, S.; Bøtner, A.; Butterworth, A.; Calistri, P.; Depner, K.; Edwards, S.; Garin-Bastuji, B.; Good, M.; Schmidt, C.G.; Michel, V. Assessment of listing and categorisation of animal diseases within the framework of the Animal Health Law (Regulation (EU) No 2016/429): Enzootic bovine leukosis (EBL). EFSA J. 2017, 15, 4956.

85. OIE. World Animal Health Infromation Database-Version: 1.4; World Organisation for Animal Health: Paris, France, 2009.

86. OIE. Manual of Diagnostic Tests and Vaccines for Terrestrial Animals: Chapter 2.4.11. Enzootic Bovine Leukosis, 7th ed.; World Organisation for Animal Health: Paris, France, 2012.

87. Chethanond, U.-S. The Epidemiology of Enzootic Bovine Leukosis in Dairy Cattle in New Zealand: A Thesis Presented in Partial Fulfilment of the Requirements for the Degree of. Master of Veterinary Science at Massey University. Doctoral Dissertation, Massey University, Palmerston North, New Zealand, 1999.

88. Balic, D.; Lojkic, I.; Periskic, M.; Bedekovic, T.; Jungic, A.; Lemo, N.; Roic, B.; Cac, Z.; Barbic, L.; Madic, J. Identification of a new genotype of bovine leukemia virus. Arch. Virol. 2012, 157, 1281-1290. [CrossRef]

89. Rola-Luszczak, M.; Pluta, A.; Olech, M.; Donnik, I.; Petropavlovskiy, M.; Gerilovych, A.; Vinogradova, I.; Choudhury, B.; Kuzmak, J. The molecular characterization of bovine leukaemia virus isolates from eastern Europe and Siberia and its impact on phylogeny. PLoS ONE 2013, 8, e58705. [CrossRef]

90. Moratorio, G.; Obal, G.; Dubra, A.; Correa, A.; Bianchi, S.; Buschiazzo, A.; Cristina, J.; Pritsch, O. Phylogenetic analysis of bovine leukemia viruses isolated in South America reveals diversification in seven distinct genotypes. Arch. Virol. 2010, 155, 481-489. [CrossRef] [PubMed]

91. APHIS. Bovine Leukosis Virus (BLV) on U.S. Dairy Operations, 2007; United States Department of Agriculture: Washington, DC, USA, 2008. Available online: http:/ / citeseerx.ist.psu.edu/viewdoc/download?doi=10.1.1.739.3674\&rep=rep1\&type=pdf $($ accessed on 23 October 2021).

92. SUZAN, V.M.; ONUMA, M.; AGUILAR, R.E.; MURAKAMI, Y. Prevalence of bovine herpesvirus-1, parainfluenza-3, bovine rotavirus, bovine viral diarrhea, bovine adenovirus-7, bovine leukemia virus and bluetongue virus antibodies in cattle in Mexico. Jpn. J. Vet. Res. 1983, 31, 125-132.

93. Samara, S.I.; Lima, E.G.; do Nascimento, A.A. Monitoring of enzootic bovine leukosis in dairy cattle from the Pitangueiras region in São Paulo, Brazil. Braz. J. Vet. Res. Anim. Sci. 1997, 34, 349-351. [CrossRef]

94. D'angelino, J.; Garcia, M.; Birgel, E. Epidemiological study of enzootic bovine leukosis in Brazil. Trop. Anim. Health Prod. 1998, $30,13-15$. [CrossRef] [PubMed]

95. Trono, K.G.; Pérez-Filgueira, D.M.; Duffy, S.; Borca, M.V.; Carrillo, C. Seroprevalence of bovine leukemia virus in dairy cattle in Argentina: Comparison of sensitivity and specificity of different detection methods. Vet. Microbiol. 2001, 83, 235-248. [CrossRef]

96. Hung Ch, A. Bovine leukaemia virus infection in Peru. Trop. Anim. Health Prod. 1983, 15, 61. [CrossRef] [PubMed]

97. Marin, C.; de López, N.M.; Alvarez, L.; Lozano, O.; España, W.; Castaños, H.; León, A. Epidemiology of bovine leukemia in Venezuela. Ann. De Rech. Vét. 1978, 9, 743-746.

98. Corredor-Figueroa, A.P.; Salas, S.; Olaya-Galán, N.N.; Quintero, J.S.; Fajardo, Á.; Soñora, M.; Moreno, P.; Cristina, J.; Sánchez, A.; Tobón, J. Prevalence and molecular epidemiology of bovine leukemia virus in Colombian cattle. Infect. Genet. Evol. 2020, 80, 104171. [CrossRef] [PubMed]

99. Yang, Y.; Fan, W.; Mao, Y.; Yang, Z.; Lu, G.; Zhang, R.; Zhang, H.; Szeto, C.; Wang, C. Bovine leukemia virus infection in cattle of China: Association with reduced milk production and increased somatic cell score. J. Dairy Sci. 2016, 99, 3688-3697. [CrossRef]

100. Hsieh, J.-C.; Li, C.-Y.; Hsu, W.-L.; Chuang, S.-T. Molecular epidemiological and serological studies of bovine leukemia virus in Taiwan dairy cattle. Front. Vet. Sci. 2019, 6, 427. [CrossRef]

101. Meas, S.; Ohashi, K.; Tum, S.; Chhin, M.; Te, K.; Miura, K.; Sugimoto, C.; Onuma, M. Seroprevalence of bovine immunodeficiency virus and bovine leukemia virus in draught animals in Cambodia. J. Vet. Med. Sci. 2000, 62, 779-781. [CrossRef] [PubMed]

102. Murakami, K.; Kobayashi, S.; Konishi, M.; Kameyama, K.-I.; Tsutsui, T. Nationwide survey of bovine leukemia virus infection among dairy and beef breeding cattle in Japan from 2009-2011. J. Vet. Med. Sci. 2013, 75, 1123-1126. [CrossRef] [PubMed]

103. Kobayashi, S.; Tsutsui, T.; Yamamoto, T.; Hayama, Y.; Kameyama, K.; Konishi, M.; Murakami, K. Risk factors associated with within-herd transmission of bovine leukemia virus on dairy farms in Japan. BMC Vet. Res. 2010, 6, 1. [CrossRef] [PubMed]

104. Ohno, A.; Takeshima, S.N.; Matsumoto, Y.; Aida, Y. Risk factors associated with increased bovine leukemia virus proviral load in infected cattle in Japan from 2012 to 2014. Virus Res. 2015, 210, 283-290. [CrossRef] [PubMed]

105. Ochirkhuu, N.; Konnai, S.; Odbileg, R.; Nishimori, A.; Okagawa, T.; Murata, S.; Ohashi, K. Detection of bovine leukemia virus and identification of its genotype in Mongolian cattle. Arch. Virol. 2016, 161, 985-991. [CrossRef] 
106. Polat, M.; Ohno, A.; Takeshima, S.N.; Kim, J.; Kikuya, M.; Matsumoto, Y.; Mingala, C.N.; Onuma, M.; Aida, Y. Detection and molecular characterization of bovine leukemia virus in Philippine cattle. Arch. Virol. 2015, 160, 285-296. [CrossRef]

107. Khan, M.F.; Siddique, U.; Shah, A.A.; Khan, I.; Anwar, F.; Ahmad, I.; Zeb, M.T.; Hassan, M.F.; Ali, T. Seroprevalence of Bovine Leukemia Virus (BLV) in Cattle from the North West of Pakistan. Pak. Vet. J. 2019, 40, 127-129.

108. Hafez, S.; Sharif, M.; Al-Sukayran, A.; Dela-Cruz, D. Preliminary studies on enzootic bovine leukosis in Saudi dairy farms. DTW Dtsch. Tierarztl. Wochenschr. 1990, 97, 61-63.

109. Burgu, I.; Alkan, F.; Karaoglu, T.; Bilge-Dagalp, S.; Can-Sahna, K.; Güngör, B.; Demir, B. Control and eradication programme of enzootic bovine leucosis (EBL) from selected dairy herds in Turkey. DTW Dtsch. Tierarztl. Wochenschr. 2005, 112, 271-274. [PubMed]

110. Trainin, Z.; Brenner, J. The direct and indirect economic impacts of bovine leukemia virus infection on dairy cattle. Isr. J. Vet. Med. 2005, 60, 94 .

111. Khudhair, Y.I.; Hasso, S.A.; Yaseen, N.Y.; Al-Shammari, A.M. Serological and molecular detection of bovine leukemia virus in cattle in Iraq. Emerg. Microbes Infect. 2016, 5, 1-6. [CrossRef] [PubMed]

112. Selim, A.; Megahed, A.A.; Kandeel, S.; Abdelhady, A. Risk factor analysis of bovine leukemia virus infection in dairy cattle in Egypt. Comp. Immunol. Microbiol. Infect. Dis. 2020, 72, 101517. [CrossRef] [PubMed]

113. Lewin, H.A.; Bernoco, D. Evidence for BoLA-linked resistance and susceptibility to subclinical progression of bovine leukaemia virus infection. Anim. Genet. 1986, 17, 197-207. [CrossRef] [PubMed]

114. Garcia-Etxebarria, K.; Sistiaga-Poveda, M.; Jugo, B.M. Endogenous retroviruses in domestic animals. Curr. Genom. 2014, 15, 256-265. [CrossRef] [PubMed]

115. D'Angelino, R.H.R.; Pituco, E.M.; Villalobos, E.M.C.; Harakava, R.; Gregori, F.; Del Fava, C. Detection of bovine leukemia virus in brains of cattle with a neurological syndrome: Pathological and molecular studies. BioMed Res. Int. 2013, 2013, 425646. [CrossRef] [PubMed]

116. Kettmann, R.; Burny, A.; Callebaut, I.; Droogmans, L.; Mammerickx, M.; Willems, L.; Portetelle, D. Bovine leukemia virus. In The Retroviridae; Springer: Berlin/Heidelberg, Germany, 1994; pp. 39-81.

117. Porta, N.G.; Alvarez, I.; Archilla, G.S.; Ruiz, V.; Abdala, A.; Trono, K. Experimental infection of sheep with Bovine leukemia virus (BLV): Minimum dose of BLV-FLK cells and cell-free BLV and neutralization activity of natural antibodies. Rev. Argent. Microbiol. 2019, 51, 316-323. [CrossRef]

118. Dimitrov, P.; Simeonov, K.; Todorova, K.; Ivanova, Z.; Toshkova, R.; Shikova, E.; Russev, R. Pathological features of experimental bovine leukaemia viral (BLV) infection in rats and rabbits. Bull. Vet. Inst. Pulawy 2012, 56, 115-120. [CrossRef]

119. Abdalla, E.; Weigel, K.; Byrem, T.; Rosa, G. Genetic correlation of bovine leukosis incidence with somatic cell score and milk yield in a US Holstein population. J. Dairy Sci. 2016, 99, 2005-2009. [CrossRef]

120. Burmeister, T. Oncogenic retroviruses in animals and humans. Rev. Med. Virol. 2001, 11, 369-380. [CrossRef] [PubMed]

121. Bauermann, F.V.; Ridpath, J.F.; Dargatz, D.A. Bovine leukemia virus seroprevalence among cattle presented for slaughter in the United States. J. Vet. Diagn. Investig. 2017, 29, 704-706. [CrossRef]

122. Murakami, K.; Kobayashi, S.; Konishi, M.; Kameyama, K.-i.; Yamamoto, T.; Tsutsui, T. The recent prevalence of bovine leukemia virus (BLV) infection among Japanese cattle. Vet. Microbiol. 2011, 148, 84-88. [CrossRef] [PubMed]

123. Maezawa, M.; Watanabe, K.-i.; Horiuchi, N.; Matsumoto, K.; Kobayashi, Y.; Inokuma, H. A clinical case of enzootic bovine leukosis in a 13-month-old Holstein heifer. Jpn. J. Vet. Res. 2018, 66, 209-213.

124. Oguma, K.; Suzuki, M.; Sentsui, H. Enzootic bovine leukosis in a two-month-old calf. Virus Res. 2017, 233, 120-124. [CrossRef] [PubMed]

125. Shaghayegh, A. Detection and identification of Enzootic Bovine Leukosis (EBL) in Calves in Iran. Arch. Razi Inst. 2019, 74, 321-325. [PubMed]

126. Hutchinson, H.C.; Ruggiero, V.J.; Norby, B.; Sporer, K.R.B.; Bartlett, P.C. Diagnostic Measures of Disease Progression in Cattle Following Natural Infection with Bovine Leukemia Virus. Pathogens 2021, 10, 987. [CrossRef]

127. Watanuki, S.; Takeshima, S.N.; Borjigin, L.; Sato, H.; Bai, L.; Murakami, H.; Sato, R.; Ishizaki, H.; Matsumoto, Y.; Aida, Y. Visualizing bovine leukemia virus (BLV)-infected cells and measuring BLV proviral loads in the milk of BLV seropositive dams. Vet. Res. 2019, 50, 102. [CrossRef]

128. Kobayashi, S.; Tsutsui, T.; Yamamoto, T.; Hayama, Y.; Muroga, N.; Konishi, M.; Kameyama, K.-i.; Murakami, K. The role of neighboring infected cattle in bovine leukemia virus transmission risk. J. Vet. Med. Sci. 2015, 77, 861-863. [CrossRef] [PubMed]

129. Yuan, Y.; Kitamura-Muramatsu, Y.; Saito, S.; Ishizaki, H.; Nakano, M.; Haga, S.; Matoba, K.; Ohno, A.; Murakami, H.; Takeshima, S.N.; et al. Detection of the BLV provirus from nasal secretion and saliva samples using BLV-CoCoMo-qPCR2: Comparison with blood samples from the same cattle. Virus Res. 2015, 210, 248-254. [CrossRef]

130. Foley, C.; O’Farrelly, C.; Meade, K.G. Technical note: Comparative analyses of the quality and yield of genomic DNA from invasive and noninvasive, automated and manual extraction methods. J. Dairy Sci. 2011, 94, 3159-3165. [CrossRef]

131. Mammerickx, M.; Portetelle, D.; de Clercq, K.; Burny, A. Experimental transmission of enzootic bovine leukosis to cattle, sheep and goats: Infectious doses of blood and incubation period of the disease. Leuk. Res. 1987, 11, 353-358. [CrossRef]

132. Mekata, H.; Sekiguchi, S.; Konnai, S.; Kirino, Y.; Honkawa, K.; Nonaka, N.; Horii, Y.; Norimine, J. Evaluation of the natural perinatal transmission of bovine leukaemia virus. Vet. Rec. 2015, 176, 254. [CrossRef] [PubMed] 
133. Haga, T. Enzootic Bovine Leukosis: How to prevent the disease and control the spread of BLV infection. In Proceedings of the 1st International Conference Postgraduate School Universitas Airlangga: "Implementation of Climate Change Agreement to Meet Sustainable Development Goals" (ICPSUAS 2017), Surabaya, Indonesia, 1-2 August 2017.

134. Kohara, J.; Takeuchi, M.; Hirano, Y.; Sakurai, Y.; Takahashi, T. Vector control efficacy of fly nets on preventing bovine leukemia virus transmission. J. Vet. Med. Sci. 2018, 80, 1524-1527. [CrossRef]

135. Ooshiro, M.; Konnai, S.; Katagiri, Y.; Afuso, M.; Arakaki, N.; Tsuha, O.; Murata, S.; Ohashi, K. Horizontal transmission of bovine leukemia virus from lymphocytotic cattle, and beneficial effects of insect vector control. Vet. Rec. 2013, 173, 527. [CrossRef] [PubMed]

136. Selim, A.; Radwan, A. Seroprevalence and molecular characterization of West Nile Virus in Egypt. Comp. Immunol. Microbiol. Infect. Dis. 2020, 71, 101473. [CrossRef] [PubMed]

137. Selim, A.; Ali, A.-F. Seroprevalence and risk factors for C. burentii infection in camels in Egypt. Comp. Immunol. Microbiol. Infect. Dis. 2020, 68, 101402. [CrossRef] [PubMed]

138. Mekata, H.; Yamamoto, M.; Hayashi, T.; Kirino, Y.; Sekiguchi, S.; Konnai, S.; Horii, Y.; Norimine, J. Cattle with a low bovine leukemia virus proviral load are rarely an infectious source. Jpn. J. Vet. Res. 2018, 66, 157-163.

139. Konishi, M.; Ishizaki, H.; Kameyama, K.-I.; Murakami, K.; Yamamoto, T. The effectiveness of colostral antibodies for preventing bovine leukemia virus (BLV) infection in vitro. BMC Vet. Res. 2018, 14, 419. [CrossRef] [PubMed]

140. Andoh, K.; Nishimori, A.; Sakumoto, R.; Hayashi, K.-G.; Hatama, S. The chemokines CCL2 and CXCL10 produced by bovine endometrial epithelial cells induce migration of bovine B lymphocytes, contributing to transuterine transmission of BLV infection. Vet. Microbiol. 2020, 242, 108598. [CrossRef]

141. Erskine, R.J.; Bartlett, P.C.; Byrem, T.M.; Render, C.L.; Febvay, C.; Houseman, J.T. Herd-level determinants of bovine leukaemia virus prevalence in dairy farms. J. Dairy Res. 2012, 79, 445-450. [CrossRef]

142. Benitez, O.J.; Roberts, J.N.; Norby, B.; Bartlett, P.C.; Takeshima, S.-N.; Watanuki, S.; Aida, Y.; Grooms, D.L. Breeding bulls as a potential source of bovine leukemia virus transmission in beef herds. J. Am. Vet. Med. Assoc. 2019, 254, 1335-1340. [CrossRef]

143. Stott, M.L.; Thurmond, M.C.; Dunn, S.J.; Osburn, B.I.; Stott, J.L. Integrated bovine leukosis proviral DNA in T helper and T cytotoxic/suppressor lymphocytes. J. Gen. Virol. 1991, 72 Pt 2, 307-315. [CrossRef] [PubMed]

144. Dube, S.; Bachman, S.; Spicer, T.; Love, J.; Choi, D.; Esteban, E.; Ferrer, J.F.; Poiesz, B.J. Degenerate and specific PCR assays for the detection of bovine leukaemia virus and primate T cell leukaemia/lymphoma virus pol DNA and RNA: Phylogenetic comparisons of amplified sequences from cattle and primates from around the world. J. Gen. Virol. 1997, 78, 1389-1398. [CrossRef] [PubMed]

145. Cantor, G.H.; Pritchard, S.M.; Dequiedt, F.; Willems, L.; Kettmann, R.; Davis, W.C. CD5 is dissociated from the B-cell receptor in B cells from bovine leukemia virus-infected, persistently lymphocytotic cattle: Consequences to B-cell receptor-mediated apoptosis. J. Virol. 2001, 75, 1689-1696. [CrossRef]

146. Park, B.H.; Matuschke, B.; Lavi, E.; Gaulton, G.N. A point mutation in the env gene of a murine leukemia virus induces syncytium formation and neurologic disease. J. Virol. 1994, 68, 7516-7524. [CrossRef]

147. Willems, L.; Burny, A.; Collete, D.; Dangoisse, O.; Dequiedt, F.; Gatot, J.S.; Kerkhofs, P.; Lefebvre, L.; Merezak, C.; Peremans, T.; et al. Genetic determinants of bovine leukemia virus pathogenesis. AIDS Res. Hum. Retrovir. 2000, 16, 1787-1795. [CrossRef] [PubMed]

148. Gatot, J.S.; Callebaut, I.; Van Lint, C.; Demonte, D.; Kerkhofs, P.; Portetelle, D.; Burny, A.; Willems, L.; Kettmann, R Bovine leukemia virus SU protein interacts with zinc, and mutations within two interacting regions differently affect viral fusion and infectivity in vivo. J. Virol. 2002, 76, 7956-7967. [CrossRef]

149. Camargos, M.F.; Pereda, A.; Stancek, D.; Rocha, M.A.; dos Reis, J.K.; Greiser-Wilke, I.; Leite, R.C. Molecular characterization of the env gene from Brazilian field isolates of Bovine leukemia virus. Virus Genes 2007, 34, 343-350. [CrossRef]

150. Tanaka, A.S.; Komuro, K. Targeted rearrangement of a chromosomal repeat sequence by transfection of a homologous DNA sequence using purified integrase. Gene Ther. 2005, 12, 783-794. [CrossRef]

151. EFSA Panel on Animal Health and Welfare (AHAW). Scientific Opinion on Enzootic Bovine Leukosis. Eur. Food Saf. Auth. (EFSA) 2015, 13, 4188 .

152. De Brogniez, A.; Mast, J.; Willems, L. Determinants of the Bovine Leukemia Virus Envelope Glycoproteins Involved in Infectivity, Replication and Pathogenesis. Viruses 2016, 8, 88. [CrossRef]

153. Gillet, N.; Florins, A.; Boxus, M.; Burteau, C.; Nigro, A.; Vandermeers, F.; Balon, H.; Bouzar, A.-B.; Defoiche, J.; Burny, A. Mechanisms of leukemogenesis induced by bovine leukemia virus: Prospects for novel anti-retroviral therapies in human. Retrovirology 2007, 4, 18. [CrossRef] [PubMed]

154. Schwartz, I.; Levy, D. Pathobiology of bovine leukemia virus. Vet. Res. 1994, 25, 521-536. [PubMed]

155. Alvarez, I.; Gutiérrez, G.; Gammella, M.; Martínez, C.; Politzki, R.; González, C.; Caviglia, L.; Carignano, H.; Fondevila, N.; Poli, M.; et al. Evaluation of total white blood cell count as a marker for proviral load of bovine leukemia virus in dairy cattle from herds with a high seroprevalence of antibodies against bovine leukemia virus. Am. J. Vet. Res. 2013, 74, 744-749. [CrossRef] [PubMed]

156. Kahn, C.; Line, S. The Merck Veterinary Manual. Bovine Leukosis; Merck and Company: White House Station, NJ, USA, 2010.

157. Zaghawa, A.; Beier, D.; Abd El-Rahim, I.; El-Ballal, S.; Karim, I.; Conraths, F.; Marquardt, O. An outbreak of enzootic bovine leukosis in upper egypt: Clinical, laboratory and molecular-epidemiological studies. J. Vet. Med. Ser. B 2002, 49, 123-129. [CrossRef] 
158. Sparling, A.M. An unusual presentation of enzootic bovine leukosis. Can. Vet. J. 2000, 41, 315. [PubMed]

159. Uchiyama, J.; Murakami, H.; Sato, R.; Mizukami, K.; Suzuki, T.; Shima, A.; Ishihara, G.; Sogawa, K.; Sakaguchi, M. Examination of the fecal microbiota in dairy cows infected with bovine leukemia virus. Vet. Microbiol. 2020, 240, 108547. [CrossRef]

160. Blagitz, M.G.; Souza, F.N.; Batista, C.F.; Azevedo, L.F.F.; Sanchez, E.M.R.; Diniz, S.A.; Silva, M.X.; Haddad, J.P.; Della Libera, A.M.M.P. Immunological implications of bovine leukemia virus infection. Res. Vet. Sci. 2017, 114, 109-116. [CrossRef]

161. Patel, J.R.; Heldens, J.G.M.; Bakonyi, T.; Rusvai, M. Important mammalian veterinary viral immunodiseases and their control. Vaccine 2012, 30, 1767-1781. [CrossRef]

162. Ferrer, J.F.; Kenyon, S.J.; Gupta, P. Milk of dairy cows frequently contains a leukemogenic virus. Science 1981, $213,1014-1016$. [CrossRef]

163. McClure, H.M.; Keeling, M.E.; Custer, R.P.; Marshak, R.R.; Abt, D.A.; Ferrer, J.F. Erythroleukemia in two infant chimpanzees fed milk from cows naturally infected with the bovine C-type virus. Cancer Res. 1974, 34, 2745-2757.

164. Johnson, R.; Kaneene, J.B. Bovine leukemia virus and enzootic bovine leukosis. Vet. Bull. 1992, 62, $287-312$.

165. Bender, A.P.; Robison, L.L.; Kashmiri, S.; McClain, K.L.; Woods, W.G.; Smithson, W.A.; Heyn, R.; Finlay, J.; Schuman, L.M.; Renier, C. No involvement of bovine leukemia virus in childhood acute lymphoblastic leukemia and non-Hodgkin's lymphoma. Cancer Res. 1988, 48, 2919-2922. [PubMed]

166. Lee, J.; Kim, Y.; Kang, C.S.; Cho, D.H.; Shin, D.H.; Yum, Y.N.; Oh, J.H.; Kim, S.H.; Hwang, M.S.; Lim, C.J. Investigation of the bovine leukemia virus proviral DNA in human leukemias and lung cancers in Korea. J. Korean Med. Sci. 2005, 20, 603-606. [CrossRef]

167. Zhang, R.; Jiang, J.; Sun, W.; Zhang, J.; Huang, K.; Gu, X.; Yang, Y.; Xu, X.; Shi, Y.; Wang, C. Lack of association between bovine leukemia virus and breast cancer in Chinese patients. Breast Cancer Res. 2016, 18, 1-2. [CrossRef] [PubMed]

168. Gillet, N.A.; Willems, L. Whole genome sequencing of 51 breast cancers reveals that tumors are devoid of bovine leukemia virus DNA. Retrovirology 2016, 13, 1-7. [CrossRef] [PubMed]

169. Kohara, J.; Konnai, S.; Onuma, M. Experimental transmission of Bovine leukemia virus in cattle via rectal palpation. Jpn. J. Vet. Res. 2006, 54, 25-30.

170. Jimba, M.; Takeshima, S.N.; Murakami, H.; Kohara, J.; Kobayashi, N.; Matsuhashi, T.; Ohmori, T.; Nunoya, T.; Aida, Y. BLV-CoCoMo-qPCR: A useful tool for evaluating bovine leukemia virus infection status. BMC Vet. Res. 2012, 8, 167. [CrossRef] [PubMed]

171. Monti, G.E.; Frankena, K.; Engel, B.; Buist, W.; Tarabla, H.D.; de Jong, M.C. Evaluation of a new antibody-based enzyme-linked immunosorbent assay for the detection of bovine leukemia virus infection in dairy cattle. J. Vet. Diagn. Investig. 2005, 17, 451-457. [CrossRef]

172. Naif, H.M.; Daniel, R.C.; Cougle, W.G.; Lavin, M.F. Early detection of bovine leukemia virus by using an enzyme-linked assay for polymerase chain reaction-amplified proviral DNA in experimentally infected cattle. J. Clin. Microbiol. 1992, 30, 675-679. [CrossRef]

173. Kurdi, A.; Blankenstein, P.; Marquardt, O.; Ebner, D. Serologic and virologic investigations on the presence of BLV infection in a dairy herd in Syria. Berl. Munch Tierarztl. Wochenschr. 1999, 112, 18-23.

174. Levy, D.; Deshayes, L.; Parodi, A.L.; Levy, J.P.; Stephenson, J.R.; Devare, S.G.; Gilden, R.V. Bovine leukemia virus specific antibodies among French cattle. II. Radioimmunoassay with the major structural protein (BLV p24). Int. J. Cancer 1977, 20, 543-550. [CrossRef]

175. Nguyen, V.K.; Maes, R.F. Evaluation of an enzyme-linked immunosorbent assay for detection of antibodies to bovine leukemia virus in serum and milk. J. Clin. Microbiol. 1993, 31, 979-981. [CrossRef] [PubMed]

176. Fukai, K.; Sato, M.; Kawara, M.; Hoshi, Z.; Ueno, S.; Chyou, N.; Akashi, H. A case of an embryo transfer calf infected with bovine leukemia virus from the recipient cow. Zent. Vet. B 1999, 46, 511-515. [CrossRef]

177. Jimba, M.; Takeshima, S.; Matoba, K.; Endoh, D.; Aida, Y. BLV-CoCoMo-qPCR: Quantitation of bovine leukemia virus proviral load using the CoCoMo algorithm. Retrovirology 2010, 7, 91. [CrossRef] [PubMed]

178. Somura, Y.; Sugiyama, E.; Fujikawa, H.; Murakami, K. Comparison of the copy numbers of bovine leukemia virus in the lymph nodes of cattle with enzootic bovine leukosis and cattle with latent infection. Arch. Virol. 2014, 159, 2693-2697. [CrossRef] [PubMed]

179. Lew, A.E.; Bock, R.E.; Miles, J.; Cuttell, L.B.; Steer, P.; Nadin-Davis, S.A. Sensitive and specific detection of bovine immunodeficiency virus and bovine syncytial virus by $5^{\prime}$ Taq nuclease assays with fluorescent $3^{\prime}$ minor groove binder-DNA probes. J. Virol. Methods 2004, 116, 1-9. [CrossRef]

180. Tajima, S.; Ikawa, Y.; Aida, Y. Complete bovine leukemia virus (BLV) provirus is conserved in BLV-infected cattle throughout the course of B-cell lymphosarcoma development. J. Virol. 1998, 72, 7569-7576. [CrossRef]

181. Tajima, S.; Tsukamoto, M.; Aida, Y. Latency of viral expression in vivo is not related to CpG methylation in the U3 region and part of the R region of the long terminal repeat of bovine leukemia virus. J. Virol. 2003, 77, 4423-4430. [CrossRef]

182. Takeshima, S.-N.; Watanuki, S.; Ishizaki, H.; Matoba, K.; Aida, Y. Development of a direct blood-based PCR system to detect BLV provirus using CoCoMo primers. Arch. Virol. 2016, 161, 1539-1546. [CrossRef] [PubMed]

183. Tawfeeq, M.M.; Horiuchi, N.; Kobayashi, Y.; Furuoka, H.; Inokuma, H. Evaluation of gene expression in peripheral blood cells as a potential biomarker for enzootic bovine leukosis. J. Vet. Med. Sci. 2013, 75, 1213-1217. [CrossRef] 
184. El Daous, H.; Mitoma, S.; Elhanafy, E.; Thi Nguyen, H.; Thi Mai, N.; Hara, A.; Duangtathip, K.; Takezaki, Y.; Kaneko, C.; Norimine, J. Establishment of a novel diagnostic test for Bovine leukaemia virus infection using direct filter PCR. Transbound. Emerg. Dis. 2020, 67, 1671-1676. [CrossRef] [PubMed]

185. Gutiérrez, G.; Alvarez, I.; Fondevila, N.; Politzki, R.; Lomónaco, M.; Rodriguez, S.; Santos, M.D.; Trono, K. Detection of bovine leukemia virus specific antibodies using recombinant p24-ELISA. Vet. Microbiol. 2009, 137, 224-234. [CrossRef] [PubMed]

186. Kuczewski, A.; Orsel, K.; Barkema, H.W.; Kelton, D.F.; Hutchins, W.A.; van der Meer, F.J. Evaluation of 5 different ELISA for the detection of bovine leukemia virus antibodies. J. Dairy Sci. 2018, 101, 2433-2437. [CrossRef] [PubMed]

187. Choi, K.Y.; Liu, R.B.; Buehring, G.C. Relative sensitivity and specificity of agar gel immunodiffusion, enzyme immunosorbent assay, and immunoblotting for detection of anti-bovine leukemia virus antibodies in cattle. J. Virol. Methods 2002, 104, 33-39. [CrossRef]

188. De Giuseppe, A.; Feliziani, F.; Rutili, D.; De Mia, G.M. Expression of the bovine leukemia virus envelope glycoprotein (gp51) by recombinant baculovirus and its use in an enzyme-linked immunosorbent assay. Clin. Diagn. Lab. Immunol. 2004, 11, 147-151. [CrossRef]

189. Bai, L.; Yokoyama, K.; Watanuki, S.; Ishizaki, H.; Takeshima, S.-N.; Aida, Y. Development of a new recombinant p24 ELISA system for diagnosis of bovine leukemia virus in serum and milk. Arch. Virol. 2019, 164, 201-211. [CrossRef]

190. Kobayashi, S.; Hidano, A.; Tsutsui, T.; Yamamoto, T.; Hayama, Y.; Nishida, T.; Muroga, N.; Konishi, M.; Kameyama, K.; Murakami, K. Analysis of risk factors associated with bovine leukemia virus seropositivity within dairy and beef breeding farms in Japan: A nationwide survey. Res. Vet. Sci. 2014, 96, 47-53. [CrossRef]

191. Endoh, D.; Mizutani, T.; Kirisawa, R.; Maki, Y.; Saito, H.; Kon, Y.; Morikawa, S.; Hayashi, M. Species-independent detection of RNA virus by representational difference analysis using non-ribosomal hexanucleotides for reverse transcription. Nucleic Acids Res. 2005, 33, e65. [CrossRef]

192. Petersen, M.; Alvarez, I.; Trono, K.; Jaworski, J. Quantification of bovine leukemia virus proviral DNA using a low-cost real-time polymerase chain reaction. J. Dairy Sci. 2018, 101, 6366-6374. [CrossRef]

193. Lojkić, I.; Balić, D.; Rudan, N.; Kovačić, M.; Čač, Ž.; Periškić, M.; Bedeković, T.; Roić, B.; Ciglar Grozdanić, I. Eradication of bovine leukosis virus on a diary farm through improved virus detection. Vet. Arh. 2013, 83, 581-591.

194. Klintevall, K.; Ballagi-Pordany, A.; Näslund, K.; Belak, S. Bovine leukaemia virus: Rapid detection of proviral DNA by nested PCR in blood and organs of experimentally infected calves. Vet. Microbiol. 1994, 42, 191-204. [CrossRef]

195. Molloy, J.B.; Dimmock, C.K.; Eaves, F.W.; Bruyeres, A.G.; Cowley, J.A.; Ward, W.H. Control of bovine leukaemia virus transmission by selective culling of infected cattle on the basis of viral antigen expression in lymphocyte cultures. Vet. Microbiol. 1994, 39, 323-333. [CrossRef]

196. Marawan, M.A. Molecular Studies on Bovine Leukemia Virus. Ph.D. Thesis, Faculty of Veterinary Medicine, Benha University, Banha, Egypt, 2017.

197. Selim, A.; El-Haig, M.; Galila, E.S.; Gaede, W. Direct detection of Mycobacterium avium subsp. Paratuberculosis in bovine milk by multiplex Real-time PCR. Anim. Sci. Pap. Rep. 2013, 31, 291-302. [CrossRef]

198. Elhaig, M.M.; Selim, A.; Mandour, A.S.; Schulz, C.; Hoffmann, B. Prevalence and molecular characterization of peste des petits ruminants virus from Ismailia and Suez, Northeastern Egypt, 2014-2016. Small Rumin. Res. 2018, 169, 94-98. [CrossRef]

199. Selim, A.; Attia, K.; Ramadan, E.; Hafez, Y.M.; Salman, A. Seroprevalence and molecular characterization of Brucella species in naturally infected cattle and sheep. Prev. Vet. Med. 2019, 171, 104756. [CrossRef]

200. Selim, A.; Almohammed, H.; Abdelhady, A.; Alouffi, A.; Alshammari, F.A. Molecular detection and risk factors for Anaplasma platys infection in dogs from Egypt. Parasites Vectors 2021, 14, 1-6. [CrossRef] [PubMed]

201. Takeshima, S.N.; Kitamura-Muramatsu, Y.; Yuan, Y.; Polat, M.; Saito, S.; Aida, Y. BLV-CoCoMo-qPCR-2: Improvements to the BLV-CoCoMo-qPCR assay for bovine leukemia virus by reducing primer degeneracy and constructing an optimal standard curve. Arch. Virol. 2015, 160, 1325-1332. [CrossRef]

202. Panei, C.J.; Takeshima, S.-N.; Omori, T.; Nunoya, T.; Davis, W.C.; Ishizaki, H.; Matoba, K.; Aida, Y. Estimation of bovine leukemia virus (BLV) proviral load harbored by lymphocyte subpopulations in BLV-infected cattle at the subclinical stage of enzootic bovine leucosis using BLV-CoCoMo-qPCR. BMC Vet. Res. 2013, 9, 95. [CrossRef]

203. Sato, H.; Watanuki, S.; Murakami, H.; Sato, R.; Ishizaki, H.; Aida, Y. Development of a luminescence syncytium induction assay (LuSIA) for easily detecting and quantitatively measuring bovine leukemia virus infection. Arch. Virol. 2018, 163, 1519-1530. [CrossRef] [PubMed]

204. Sato, H.; Watanuki, S.; Bai, L.; Borjigin, L.; Ishizaki, H.; Matsumoto, Y.; Hachiya, Y.; Sentsui, H.; Aida, Y. A sensitive luminescence syncytium induction assay (LuSIA) based on a reporter plasmid containing a mutation in the glucocorticoid response element in the long terminal repeat U3 region of bovine leukemia virus. Virol. J. 2019, 16, 66. [CrossRef]

205. Sato, H.; Bai, L.; Borjigin, L.; Aida, Y. Overexpression of bovine leukemia virus receptor SLC7A1/CAT1 enhances cellular susceptibility to BLV infection on luminescence syncytium induction assay (LuSIA). Virol. J. 2020, 17, 1-6. [CrossRef]

206. Suzuki, T.; Ikeda, H.; Mase, M. Restricted viral cDNA synthesis in cell lines that fail to support productive infection by bovine leukemia virus. Arch. Virol. 2018, 163, 2415-2422. [CrossRef] [PubMed]

207. OIE. Enzootic Bovine Leucosis, OIE Manual of Standers for Diagnostic Tests and Vaccines; OIE: Paris, France, 2000; pp. 371-380. Available online: https:/ / pubag.nal.usda.gov / catalog/36672 (accessed on 23 October 2021). 
208. Bai, L.; Hirose, T.; Assi, W.; Wada, S.; Takeshima, S.-N.; Aida, Y. Bovine Leukemia Virus Infection Affects Host Gene Expression Associated with DNA Mismatch Repair. Pathogens 2020, 9, 909. [CrossRef] [PubMed]

209. Souza, F.N.; Monteiro, A.M.; dos Santos, P.R.; Sanchez, E.M.R.; Blagitz, M.G.; Latorre, A.O.; Neto, A.M.F.; Gidlund, M.; Della Libera, A.M. Antioxidant status and biomarkers of oxidative stress in bovine leukemia virus-infected dairy cows. Vet. Immunol. Immunopathol. 2011, 143, 162-166. [CrossRef] [PubMed]

210. Krasnikova, E.S.; Krasnikov, A.V.; Annikov, V.V.; Rykhlov, A.S.; Galiullin, A.K.; Alimov, A.M. Analysis of hemo-biochemical status of cows infected with retroviruse. Res. J. Pharm. Biol. Chem. Sci. 2018, 9, 1122-1128.

211. Sandev, N.; Zapryanova, D.; Stoycheva, I.; Rusenova, N.; Mircheva, T. Investigation of some hematological and blood biochemical parameters in cattle spontaneously infected with bovine leukosis virus. Maced. Vet. Rev. 2013, 36, 107-110.

212. Ali, A.-F.; Selim, A.; Manaa, E.A.; Abdelrahman, A.; Sakr, A. Oxidative state markers and clinicopathological findings associated with bovine leukemia virus infection in cattle. Microb. Pathog. 2019, 136, 103662. [CrossRef]

213. Notsu, K.; Hashida, S.; Mitoma, S.; Kubo, M.; Arikawa, G.; Agah, M.A.; El-Khaiat, H.M.; Mai, T.N.; Nguyen, T.H.; Elhanafy, E. Assessment of Hematological Parameters and Carcass Weight in Bovine Leukemia Virus Infection in Slaughtered Beef Cattle. J. Vet. Epidemiol. 2018, 22, 43-48. [CrossRef]

214. Ruiz, V.; Porta, N.G.; Lomónaco, M.; Trono, K.; Alvarez, I. Bovine leukemia virus infection in neonatal calves. Risk factors and control measures. Front. Vet. Sci. 2018, 5, 267. [CrossRef]

215. Nishiike, M.; Haoka, M.; Doi, T.; Kohda, T.; Mukamoto, M. Development of a preliminary diagnostic measure for bovine leukosis in dairy cows using peripheral white blood cell and lymphocyte counts. J. Vet. Med. Sci. 2016, 78, 1145-1151. [CrossRef]

216. Hutchinson, H.C.; Norby, B.; Droscha, C.J.; Sordillo, L.M.; Coussens, P.M.; Bartlett, P.C. Bovine leukemia virus detection and dynamics following experimental inoculation. Res. Vet. Sci. 2020, 133, 269-275. [CrossRef] [PubMed]

217. Hayashi, T.; Mekata, H.; Sekiguchi, S.; Kirino, Y.; Mitoma, S.; Honkawa, K.; Horii, Y.; Norimine, J. Cattle with the BoLA class II DRB3* 0902 allele have significantly lower bovine leukemia proviral loads. J. Vet. Med. Sci. 2017, 79, 1552-1555. [CrossRef]

218. Notsu, K.; Wiratsudakul, A.; Mitoma, S.; El Daous, H.; Kaneko, C.; El-Khaiat, H.M.; Norimine, J.; Sekiguchi, S. Quantitative Risk Assessment for the Introduction of Bovine Leukemia Virus-Infected Cattle Using a Cattle Movement Network Analysis. Pathogens 2020, 9, 903. [CrossRef]

219. Bartlett, P.C.; Ruggiero, V.J.; Hutchinson, H.C.; Droscha, C.J.; Norby, B.; Sporer, K.R.; Taxis, T.M. Current Developments in the Epidemiology and Control of Enzootic Bovine Leukosis as Caused by Bovine Leukemia Virus. Pathogens 2020, 9, 1058. [CrossRef] [PubMed]

220. Kanno, T.; Ishihara, R.; Hatama, S.; Oue, Y.; Edamatsu, H.; Konno, Y.; Tachibana, S.; Murakami, K. Effect of freezing treatment on colostrum to prevent the transmission of bovine leukemia virus. J. Vet. Med. Sci. 2014, 76, 255-257. [CrossRef] [PubMed]

221. Otsuki, H.; Takeshima, S.-n.; Aida, Y. Generation of virus-like particle as a vaccine strategy against bovine leukemia virus. Retrovirology 2015, 12, P47. [CrossRef]

222. Bai, L.; Sato, H.; Kubo, Y.; Wada, S.; Aida, Y. CAT1/SLC7A1 acts as a cellular receptor for bovine leukemia virus infection. FASEB J. 2019, 33, 14516-14527. [CrossRef] [PubMed]

223. Bai, L.; Takeshima, S.-N.; Isogai, E.; Kohara, J.; Aida, Y. Novel CD8+ cytotoxic T cell epitopes in bovine leukemia virus with cattle. Vaccine 2015, 33, 7194-7202. [CrossRef]

224. Suzuki, A. Development and Characterisation of Recombinant LSDV-Vectored Dual Vaccines against Bovine Leukaemia Virus and Lumpy Skin Disease Virus. Master's Thesis, University of Cape Town, Cape Town, South Africa, 2019.

225. Abdala, A.; Alvarez, I.; Brossel, H.; Calvinho, L.; Carignano, H.; Franco, L.; Gazon, H.; Gillissen, C.; Hamaidia, M.; Hoyos, C. BLV: Lessons on vaccine development. Retrovirology 2019, 16, 26. [CrossRef] 